\title{
ipen
}

INSTITUTO DE PESQUISAS ENERGÉTICAS E NUCLEARES

Autarquia associada à Universidade de São Paulo

AVALIAÇÃO DO PALMITO PUPUNHA (Bactris gasipaes Kunth) PROCESSADO POR RADIÇÃO IONIZANTE

PRISCILA VIEIRA DA SILVA

Dissertação apresentada como parte dos requisitos para obtenção do grau de mestre em ciências na área de tecnologia nuclear aplicações.

Orientador:

Dra. Anna Lucia C. H. Villavicencio

SÃO PAULO

2009 


\title{
INSTITUTO DE PESQUISAS ENERGÉTICAS E NUCLEARES
}

Autarquia Associada à Universidade de São Paulo

\section{AVALIAÇÃO DO PALMITO PUPUNHA (Bactris gasipaes Kunth) PROCESSADO POR RADIÇÃO IONIZANTE}

\author{
PRISCILA VIEIRA DA SILVA
}

Dissertação apresentada como parte dos requisitos para obtenção do Grau de Mestre em Ciências na Área de Tecnologia Nuclear Aplicações.

Orientador:

Dra. Anna Lucia C. H. Villavicencio

\section{SÃO PAULO}

2009 
Aos meus pais, Osvaldo e Nilcéa meu irmão Wagner e ao meu eterno amor Camilo, simplesmente por tudo. 


\section{AGRADECIMENTOS}

À Dra. Anna Lucia C. H. Villavicencio, pela oportunidade concedida, pela orientação que desde a iniciação científica me preparou e me incentivou para a conclusão deste trabalho, pela amizade, pelo carinho, pelos conselhos, pelas dicas e principalmente pelos bons momentos compartilhados;

Ao Khalil Yepes Hojeije da "Floresta Indústria e Comércio" pela disponibilidade em ajudar-me nas análises sensoriais assim como na disponibilidade das amostras cedidas para a conclusão deste trabalho e também pela atenção, carinho, dicas, paciência, compreensão. Muito Obrigada!

Ao Professor Dr. Benedito Corrêa do Instituto de Ciências Biomédicas, Departamento de Microbiologia da Universidade de São Paulo, pelo apoio, dicas e ensinamentos.

Ao Professor Dr. Ronaldo Nogueira de Moraes Pitombo Chefe do Departamento de Tecnologia Bioquímico-Farmacêutica da Faculdade de Ciências Farmacêuticas da USP, pela atenção e apoio na realização das análises de cor.

Ao IPEN, especialmente ao Centro de Tecnologia das Radiações, representado pelo Dr. Wilson Aparecido Parejo Calvo, gerente do CTR, e pela Dra. Margarida Hamada, chefe de divisão de pesquisa e desenvolvimento do CTR, pelo apoio;

À MSc. Yasco Kodama e ao Paulo de Souza Santos por ajudarem no tratamento por radiação das amostras no irradiador multi-propósito;

Aos engenheiros Elizabeth Somessari e Carlos Gaia da Silveira, pelo constante auxílio no processamento por irradiação das amostras no Acelerador de elétrons;

Ao professor Valter Arthur pela valiosa colaboração, desde o projeto inicial até a conclusão.

Ao Marcos e à Claudia pelo imprescindível auxílio nos assuntos administrativos; 
Aos colegas do laboratório, com os quais dividi grande parte do meu tempo e que inúmeras vezes me ajudaram na realização deste trabalho: Simone, Ingrid, Patrícia, Camilo, Michel, Renato, Gustavo, Débora, Fernanda, Thaíse, Renata, Vladimir e Reginaldo;

Ao Camilo, pela paciência, colaboração, incentivo, carinho, amor e pela harmonia dos bons momentos que passamos juntos nesta jornada.

À CNEN, pelo auxílio financeiro, sem o qual o desenvolvimento deste projeto seria dificultado.

Aos demais profissionais do Centro de Tecnologia das Radiações, pósgraduandos e alunos de iniciação científica pelo convívio;

Aos meus pais, Osvaldo e Nilcéa, ao meu irmão, Wagner, e a minha querida e amada avó Cida pelo constante apoio, paciência, estímulo, carinho e acima de tudo, pelo amor incondicional;

Aos meus amigos e colegas de curso, pelas singelas contribuições do dia-adia e a todos que, direta ou indiretamente, contribuíram para a realização deste trabalho. 
Só existem dois dias no ano que nada pode ser feito. Um se chama ontem e o outro se chama amanhã, portanto hoje é o dia certo para amar, acreditar, fazer e principalmente viver.

Dalai Lama 


\section{RESUMO}

O palmito pode ser obtido de várias espécies de palmeiras, porém a pupunha vem despertado um grande interesse pelos produtores, pois apresenta características de precocidade, rusticidade e perfilhamento, gerando um palmito de ótima qualidade e se diferenciando dos demais palmitos pela sua cor amarelada e sabor adocicado. A irradiação de alimentos têm sido empregada como medida de tratamento para garantir a segurança microbiológica destes produtos evitando infecções alimentares. Seu uso combinado com o processamento mínimo poderia aumentar a segurança e qualidade dos vegetais minimamente processados. Os objetivos deste trabalho foram avaliar o efeito da radiação gama e em feixes de elétrons no controle de bactérias; avaliar as características físicas através de análises de cor e textura em palmito pupunha in natura e minimamente processados submetidos a radiações ionizantes, armazenados sob refrigeração à $8^{\circ} \mathrm{C}$, assim como também avaliar as características sensoriais. Os resultados nas análises microbiológicas mostraram que a radiação ionizante promove diminuição da carga microbiana em ambos os tratamentos. Nas análises de cor podemos concluir que entre todos os tratamentos a amostra de 1,5 kGy apresentou mais diferença em relação as outras amostras analisadas. Nas características de textura, observamos que a radiação gama modificou a textura do palmito, ao contrário do tratamento por feixes de elétrons que não demonstrou diferença entre as amostras analisadas. Em relação à análise sensorial, a radiação gama na dose de $1,5 \mathrm{kGy}$, induziu alterações nas propriedades sensoriais para os atributos globais e de aparência. A dose de 1 kGy não causou diferença significativa, sendo assim uma dose recomendável para a irradiação do produto estudado. 


\title{
EVALUATION OF PEACH PALM (Bactris gasipaes Kunth) PROCESSED BY RADIATION
}

\begin{abstract}
The peach palm can be obtained from several species of palms, but the peach palm has attracted great interest by producers, as has characteristics of precocity, rusticity and tillering, producing a palm-quality differentiating it from other palmettos for their sweet flavor and yellowish. The food irradiation has been used as a treatment to ensure microbiological food safety of products to avoid infection. Its use combined with minimal processing could increase the safety and quality of minimally processed vegetables. We aimed at evaluating the effect of gamma radiation and electron beams to control bacteria; assess the physical characteristics through analysis of color and texture in peach palm in natura minimally processed and subjected to ionizing radiation stored at $8^{\circ} \mathrm{C}$ as well as evaluating the sensory characteristics. The results in the microbiological analysis showed that ionizing radiation promotes reduction of microbial load in both treatments. In the analysis of color we can conclude that among all the treatments the sample irradiated with $1.5 \mathrm{kGy}$ showed more differences when compared with the other samples. Observing texture characteristics we could conclude that irradiation changed the texture of the palm, unlike the treatment by electron beams that showed no difference between samples. For the sensory analysis, the gamma radiation with dose of $1.5 \mathrm{kGy}$, induced changes in sensory properties to the attributes and overall appearance. The dose of $1 \mathrm{kGy}$ caused no significant difference, so a recommended dose for the irradiation of the studied product.
\end{abstract}

Keywords: Peach palm, food irradiation, minimally processed. 


\section{SUMÁRIO}

Página

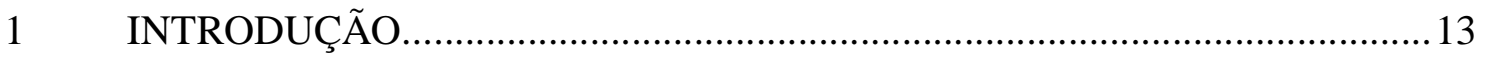

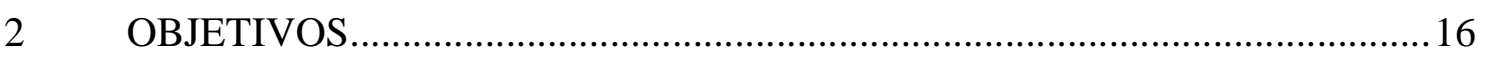

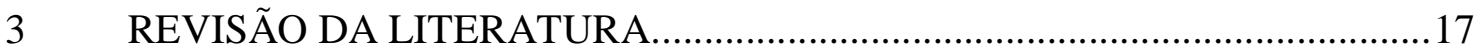

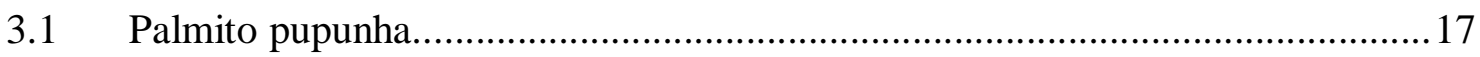

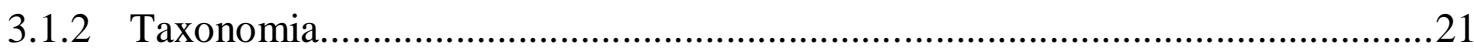

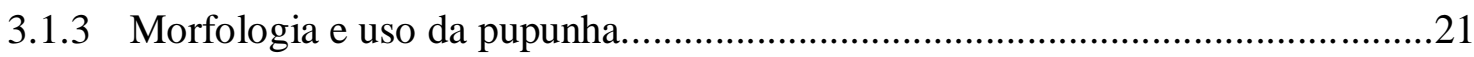

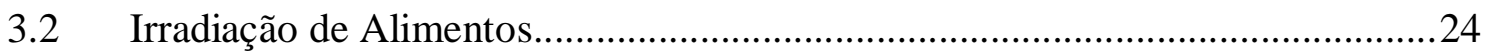

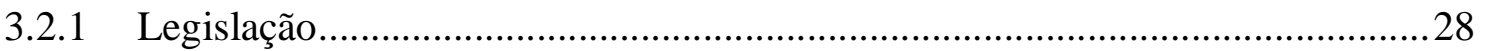

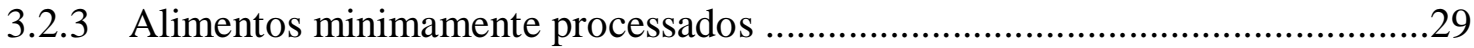

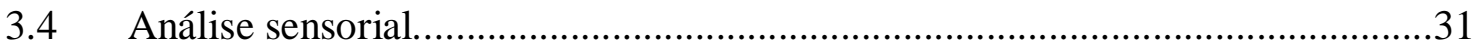

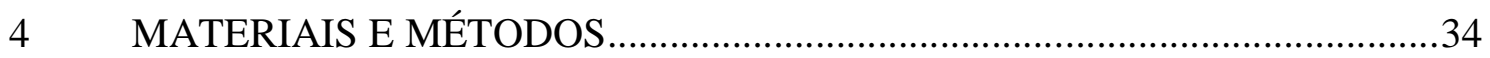

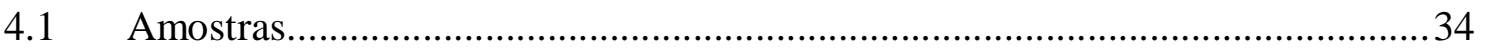

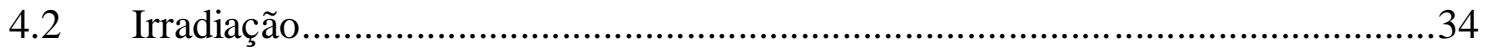

4.2.2 Preparação das amostras para o processamento de irradiação...............................35

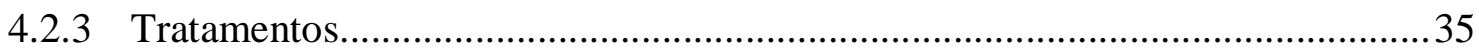

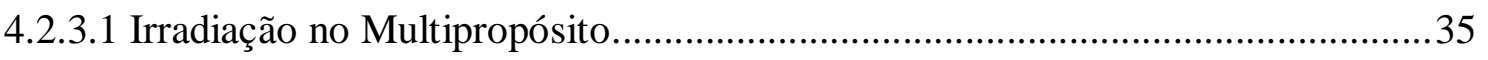

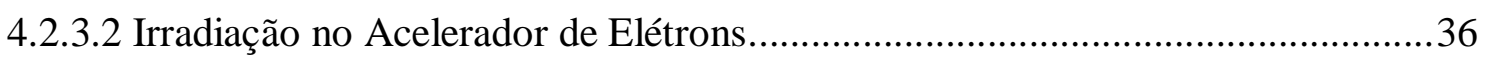

4.4 Análises Microbiológicas - Contagem de microrganismos aeróbios

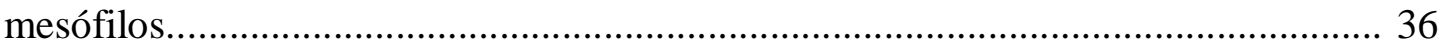

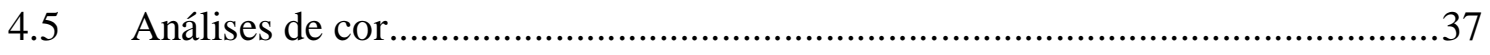

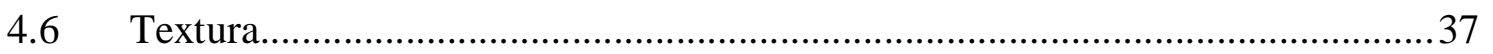

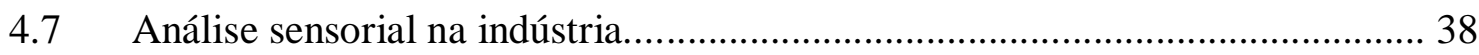

4.7.1 Aplicação do teste de "Diferença do Controle" .................................................39 


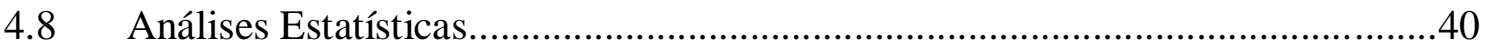

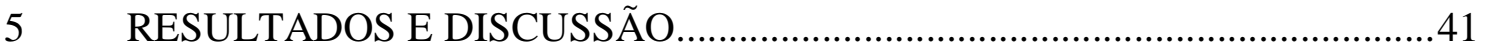

5.1 Microrganismos aeróbios mesófilos no palmito pupunha in natura irradiados no multipropósito com fonte de ${ }^{60} \mathrm{Co}$.

5.2 Microrganismos aeróbios mesófilos no palmito pupunha minimamente processado irradiado no multipropósito com fonte de ${ }^{60} \mathrm{Co}$

5.3 Microrganismos aeróbios mesófilos no palmito pupunha (parte basal) MP submetidos á radiação ionizante por Acelerador de Elétrons.

6 Análises de Cor - Amostras de palmito pupunha in natura irradiadas em Multipropósito com fonte de 60Co.

6.1 Análises de cor em amostras de palmito minimamente processados irradiados no Multipropósito com fonte de 60Co. .51

6.2 Análises de cor de palmito processado por Acelerador de Elétrons. .55

7 Análise de textura em palmito pupunha in natura irradiados em multipropósito

7.1 Análise da textura de palmito pupunha minimamente processados irradiados no multipropósito.

7.2 Análise de textura de palmito pupunha minimamente processados irradiados em acelerador de elétrons .60

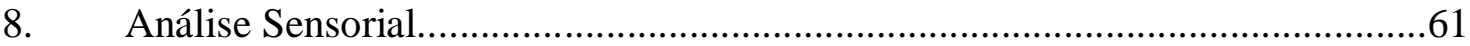

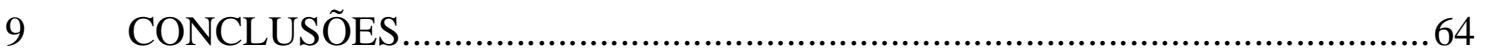

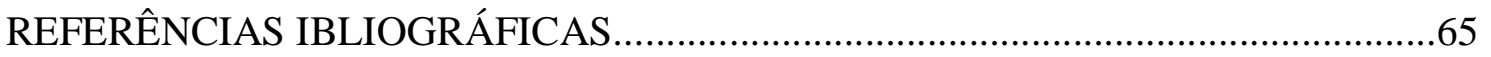




\section{LISTA DE TABELAS}

Página

TABELA 1 - Tabela 1. Resultados da análise microbiológica (média das contagens) obtidas de palmito pupunha in natura (parte: basal, nobre e foliar) processado no Multipropósito ${ }^{60} \mathrm{Co}$.......

TABELA 2 - Tabela 2. Resultados da análise microbiológica (média das contagens) obtidas de palmito pupunha MP (parte: basal, nobre e foliar) processado no Multipropósito ${ }^{60} \mathrm{Co}$. 44

TABELA 3 - Número de microrganismos aeróbios mesófilos (*UFC/g) no palmito pupunha minimamente processado (parte basal) após o processamento do produto por feixes de elétrons. 48

TABELA 4. Médias dos parâmetros $L, a$ e $b$ de palmito pupunha in natura. .50

TABELA 5. Médias dos valores $\mathrm{L}$, a e b de palmito pupunha minimamente processado e armazenados sob refrigeração de $8^{\circ} \mathrm{C}$.

TABELA 6. Médias dos valores $\mathrm{L}$, a e b de palmito pupunha minimamente processado e armazenados sob refrigeração de $8^{\circ} \mathrm{C}$, submetidos à radiação ionizante em acelerador de elétrons

TABELA 7. Textura de palmito minimamente processados irradiados por radiação gama, armazenados por 21 dias

TABELA 8. Textura de palmito in natura processados por radiação gama, armazenados por 21 dias.

TABELA 9. Textura de palmito minimamente processados irradiados por feixes de elétrons armazenados por 21 dias.

TABELA 10. Médias dos resultados da análise sensorial para os parâmetros global e de cor das partes nobre e basal de palmito. .63 


\section{LISTA DE FIGURAS}

Página

FIGURA 1 - Foto de uma palmeira de pupunha (Bastris gasipaes) .18

FIGURA 2 - Bandejas de palmito pupunha minimamente processados, disponíveis no comércio 20

FIGURA 3 - A) Palmeira de pupunha; A1) Cachos de frutos; A2) Seções transversais e perfil do fruto; A3) Coluna coberta de entrenós.

FIGURA 4 - Amostras de palmito pupunha in natura (inteiro-tolete), e amostras da parte basal e nobre de palmito pupunha minimamente processado .35

FIGURA 5 - Amostras embaladas em sacos plásticos de palmito pupunha MP para serem irradiados no acelerador de elétrons. 37

FIGURA 6 - Ficha de avaliação sensorial apresentada aos provadores. 40

FIGURA 7 - Contagens de microrganismos aeróbios mesófilos (média log UFC/g) presentes em amostras de palmito pupunha in natura (parte basal).

FIGURA 8 - Contagens de microrganismos aeróbios mesófilos (média log UFC/g) presentes em amostras de palmito pupunha in natura (parte nobre).

FIGURA 9 - Contagens de microrganismos aeróbios mesófilos (média log UFC/g) presentes em amostras de palmito pupunha in natura (parte foliar)

FIGURA 10 - Bactérias aeróbias mesófilas de palmito pupunha minimamente processado (sanitizado) irradiado no multipropósito com fonte de ${ }^{60} \mathrm{Co}$ (parte basal).. 45

FIGURA 11 - Bactérias aeróbias mesófilas de palmito pupunha minimamente processado (sanitizado) irradiado no multipropósito com fonte de ${ }^{60} \mathrm{Co}$ (parte nobre)...45

FIGURA 12 - Bactérias aeróbias mesófilas de palmito pupunha minimamente processado (sanitizado) irradiado no multipropósito com fonte de ${ }^{60} \mathrm{Co}$ (parte nobre) .46

FIGURA 13 - de microrganismos aeróbios mesófilos (média log UFC/g) presentes em amostras de palmito pupunha minimamente processado (parte basal).

FIGURA 14 - Parâmetro L (Luminosidade) para amostras de palmito pupunha in natura submetidas ao processo de radiação gama nas doses de 1 e 1,5 kGy armazenadas em diferentes períodos (valores médios). 
FIGURA 15 - Fator a (+a: vermelho, -a: verde) para amostras de palmito pupunha in natura submetidas ao processo de radiação gama nas doses de 1 e 1,5 kGy armazenadas em diferentes períodos (valores médios)

FIGURA 16 - Fator b para amostras de palmito pupunha in natura submetidas ao processo de radiação gama nas doses de 1 e 1,5 kGy armazenadas em diferentes períodos (valores médios)

FIGURA 17 - Fator L (Luminosidade) para amostras de palmito pupunha minimamente processados, submetidas ao processo de radiação gama nas doses de 1 e 1,5 kGy armazenadas sob refrigeração em diferentes períodos (valores médios)......

FIGURA 18 - Fator a (+a: vermelho, -a: verde) para amostras de palmito pupunha minimamente processados, submetidas ao processo de radiação gama nas doses de $1 \mathrm{e}$ 1,5 kGy armazenadas sob refrigeração em diferentes períodos (valores médios)............53

FIGURA 19 - Fator b de amostras de palmito pupunha minimamente processados, submetidas ao processo de radiação gama nas doses de 1 e 1,5 kGy e armazenadas sob refrigeração em diferentes períodos (valores médios).

FIGURA 20 - Fator L (Luminosidade) para amostras de palmito pupunha MP, submetidas ao processo de radiação ionizante por acelerador de elétrons, irradiados nas doses de 1 e 1,5 kGy, armazenadas sob refrigeração em diferentes períodos (valores médios). .56

FIGURA 21 - Fator a de amostras de palmito pupunha MP, submetidas ao processo de radiação ionizante por acelerador de elétrons irradiados nas doses de 1 e 1,5 kGy e armazenadas sob refrigeração em diferentes períodos (valores médios)

FIGURA 22 - Fator b de amostras de palmito pupunha MP, submetidas ao processo de radiação ionizante por acelerador de elétrons irradiados nas doses de 1 e 1,5 kGy e armazenadas sob refrigeração em diferentes períodos (valores médios) 


\section{INTRODUÇÃO}

O palmito é considerado uma iguaria tipicamente brasileira, também admirado e consumido em diversos países do mundo que o consideram um produto exótico, e o utilizam para confecção de pratos finos, tornando-se assim um produto de alto valor econômico.

A pupunheira (Bactris gasipaes Kunth) é uma espécie com elevado potencial econômico, pelo valor nutritivo dos seus frutos, que podem ser utilizados tanto na alimentação humana como na animal, e principalmente, pela extração do palmito. A expansão da cultura da pupunha tem ocorrido visando atender ao mercado consumidor de palmito (MORETTI, 2001).

A pupunha é uma palmeira originária da Região Amazônica, sendo domesticada e disseminada nesta região e na América Central por povos indígenas. É uma ótima alternativa para produção de palmito, podendo ser explorada em plantios organizados, e possui características desejáveis, tais como precocidade, perfilhamento, rendimento e qualidade do seu palmito (CHAIMSOHN, 2000). Bernhardt (1999) afirmou que a principal característica do palmito da pupunheira, sob o ponto de vista do processamento, é a sua baixa atividade enzimática com conseqüente escurecimento bastante lento, facilitando o processamento e permitindo desenvolver outras formas de comercialização do produto, com alterações mínimas nas suas características sensoriais.

A importância da pupunha é não apresentar escurecimento, fato que além de facilitar os procedimentos operacionais no momento da industrialização, permite a exploração da comercialização do palmito in natura com o mínimo de processo: sanitizado e refrigerado, oferecendo uma nova opção de consumir o palmito, além de ganhar espaço no mercado, por ser um produto natural, cuja textura, aparência e sabor são muito atrativos em relação ao palmito processado (HOJEIJE, 2006).

Hortaliças refrigeradas, como o palmito, são consideradas minimamente processadas quando fisicamente alteradas. No entanto é necessário que permaneçam no 
estado fresco. Essa transformação tecnológica, mesmo sendo mínima, produz destruição do tecido, por conseguinte, além de facilitar a contaminação microbiana, ocorre liberação de enzimas e de seus substratos, propiciando a ocorrência de reações enzimáticas que podem alterar as características sensoriais do produto (CLEMENT et al, 1999).

O palmito cultivado pode ser considerado um produto ecologicamente correto, e nestes plantios pode-se padronizar o palmito, obtendo melhor qualidade devido ao maior controle de todo o processo, desde a escolha de sementes até a industrialização do palmito (SÁ et al, 2002).

Para garantir a qualidade de um alimento, tanto do ponto de vista de saúde pública bem como para aumentar sua vida útil, existem vários métodos disponíveis para as indústrias alimentícias, sendo um deles a irradiação. A irradiação de alimentos é considerada um tratamento versátil e efetivo para a preservação, desinfestação e descontaminação dos mais diversos produtos do setor alimentício (MOLLINS et al., 2001).

As necessidades mundiais de alimentos foram aumentando e os problemas, advindos da demanda de estruturas adequadas de armazenamento e processamento, levaram a busca de novos métodos de preservação dos alimentos, tanto in natura quanto como coadjuvante dos processos industriais (VILLAVICENCIO, 1998; 2007).

Nas últimas décadas a irradiação de alimentos tem recebido atenção crescente devido às vantagens que apresenta sobre os métodos convencionais de processamento. Este método possibilita o tratamento dos alimentos após a embalagem, a conservação dos produtos em seu estado fresco, assim, alimentos perecíveis podem ser conservados por mais tempo sem perder sua qualidade e o produto praticamente não sofre alterações de temperatura (FARKAS, 2006).

O processo de irradiação pode inibir a divisão de células vivas, como microrganismos, promovendo uma alteração em seu material genético, a ponto de inibir os processos biológicos necessários para sua sobrevivência (AQUINO, 2003). Com isso, torna-se possível o armazenamento dos alimentos por um prazo mais extenso, 
comparado ao armazenamento sem irradiação previa, dispensando o uso de conservantes químicos muitas vezes nocivos a saúde. Além disso, a irradiação de alimentos atende medidas de preservação ambiental, diminuindo gastos energéticos e riscos sanitários (MONK et al, 1995; OUATTARA et al, 2002).

Em geral, o processo de irradiação nas doses recomendadas, acarreta poucas alterações químicas nos alimentos. Segundo Diehl (1992; 1995), nas doses de até 1kGy, as perdas nutricionais são consideradas insignificantes e nenhuma das alterações conhecidas encontradas nos alimentos irradiados é nociva ou perigosa, estando dentro dos limites encontrados normalmente para alimentos (DELINCÉE, 2002).

A irradiação de alimentos pode ser uma saída para aliviar muitos dos problemas de perdas de alimentos no mundo. A irradiação como método de conservação tem como objetivo reduzir as perdas devido à decomposição dos alimentos e combater os microorganismos causadores de enfermidades provenientes do alimento. Os problemas sanitários que afetam os produtos da agricultura, incluindo aqueles que interessam particularmente os países em desenvolvimento, estão associados com a contaminação biológica e química que podem ocorrer durante o cultivo destes alimentos (JAY, 2001; LEE et al, 2006).

É fundamental para este processo que se utilizem as boas práticas de fabricação (“Good Manufacturing Practices - GMP”), já que o processamento por irradiação não pode melhorar a má qualidade dos produtos alimentícios ou uma manipulação indevida, pois não reverte o processo fisiológico e químico da decomposição (DELINCÉE, 1998).

Em função do aumento do comércio internacional de alimentos, das crescentes exigências regulatórias dos mercados consumidores, cada vez mais países importadores e exportadores estão apresentando interesse na irradiação de alimentos, e desenvolvido pesquisas na aplicação prática desta tecnologia (ICGFI, 1999).

A finalidade deste projeto foi verificar os efeitos da radiação gama ${ }^{60} \mathrm{Co}$ e de acelerador de elétrons nas propriedades do palmito pupunha in natura e minimamente processados, estabelecendo a dose ideal para a conservação deste alimento. 


\section{OBJETIVOS}

O presente trabalho teve como objetivos:

- Avaliar o efeito da radiação gama e feixe de elétrons no controle de bactérias aeróbias mesófilas presentes no palmito pupunha in natura e minimamente processados.

- Avaliar as características físicas através de análises de cor e textura do palmito pupunha in natura e minimamente processados submetidos a radiações ionizantes.

- Avaliar as características sensoriais do palmito pupunha. 


\section{REVISÃO DA LITERATURA}

\subsection{Palmito Pupunha}

O sucesso da pupunheira como produtora de palmito deve-se às suas características de precocidade, produtividade e adaptação. A produção da planta é contínua durante todo o ano (colheita em 9 meses), o crescimento é rápido com o primeiro corte no segundo ano (precocidade) e cultivo perene, não necessitando de reposição anual do plantio. No Brasil é cultivada nos estados da Bahia, Espírito Santo, São Paulo e Rio de Janeiro.

A pupunha apresenta-se como alternativa de cultivo racional no contexto de diminuição de oferta e crescimento de consumo de palmito. Devido ao potencial comercial do palmito de pupunha muitos países latino-americanos estão investindo no seu cultivo e industrialização. O interesse pelo cultivo da pupunha tem aumentando fortemente, especialmente para a produção de palmito. Dois fatores estão facilitando tal aumento, ou seja, a existência de mercado em nível mundial e a disponibilidade de tecnologia para o cultivo e industrialização do palmito de pupunha (VILLACHICA, 1996).

Esta espécie apresenta um alto potencial de diversificação de produtos: raízes medicinais, estipe e folhas para construções e artesanato, flores para alimentação humana e como tempero, e folhas na alimentação animal. A pupunha é um fruto de alto valor nutricional (CAMACHO, 1970). Do estipe se retira o palmito, produto que representa seu maior potencial econômico, pois, é uma cultura de ciclo curto e altamente rentável em comparação com outras palmeiras produtoras de palmito (CLEMENT, 1987).

A palmeira Bactris gasipaes adapta-se a diferentes condições ecológicas. Ocorre próximo ao nível do mar até cerca de $2000 \mathrm{~m}$ de altitude (ALMEYDA; MARTIN, 1980). Desenvolve-se bem em temperaturas tropicais entre $24^{\circ} \mathrm{C}$ e $28^{\circ} \mathrm{C}$ e é encontrada em áreas que se diferenciam consideravelmente quanto ao regime anual de chuvas, desde 1500 até $6000 \mathrm{~mm}$, embora cresça melhor em áreas com chuvas abundantes e bem distribuídas (MORA URPÍ, 1982). 
No Brasil há grande variedade de raças e ecotipos de pupunheira. Porém o tipo inerme, isto é, com ausência de espinhos, é a que tem chamado mais atenção de pesquisadores e interessados no seu cultivo para palmito. A pupunha, especialmente a sem espinhos, possui quase todas as características desejáveis de palmeiras do gênero Euterpe, acrescidas ainda de algumas vantagens adicionais, como: crescimento acelerado (precocidade), perfilhamento, rusticidade e alta sobrevivência em campo. Com relação ao palmito propriamente dito, difere em relação ao sabor mais doce e à coloração mais amarelada. Cultivada com base em critérios técnicos adequados, no Sudeste e Paraná pode ser cortada, geralmente, a partir de 18 a 24 meses após o plantio em campo, enquanto a juçara e o açaí levam no mínimo seis anos para o primeiro corte. De seis a oito meses após o primeiro corte pode ser extraído o segundo, a partir dos perfilhos da pupunheira. Além disso, o cultivo pode ser feito em grande parte do território brasileiro. (MORA-URPÍ et al., 1993; FERREIRA, 2005; YUYAMA, 2005).

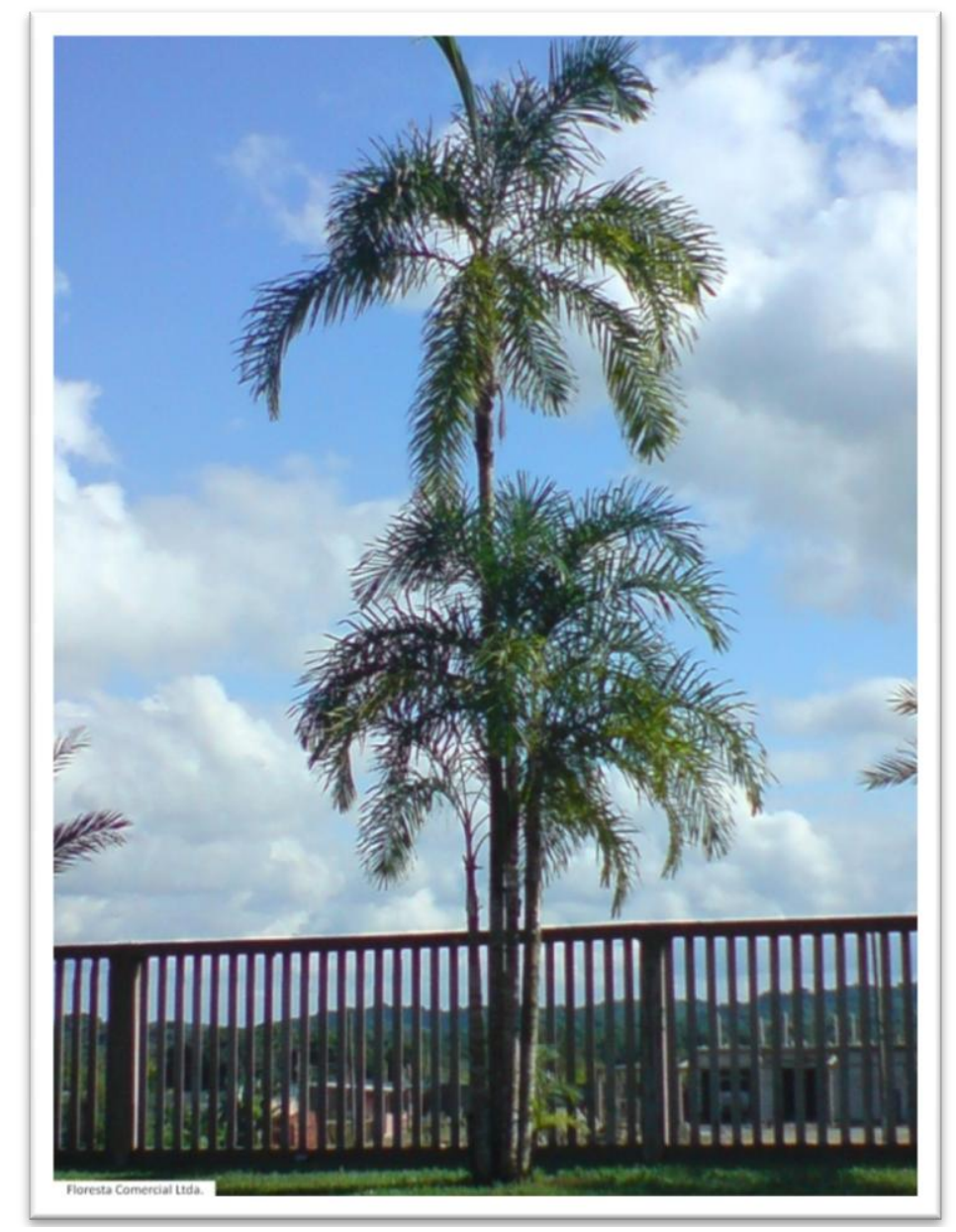

FIGURA 1 - Foto da palmeira de pupunha (Bastris gasipaes). 
O palmito in natura é o palmito bruto colhido no campo e apresenta de 3 a 4 bainhas de proteção ao redor da parte comestível e comprimento de 45 a $90 \mathrm{~cm}$. O palmito orgânico, sem agrotóxicos e sem fertilizantes químicos está sendo vendido no sudeste a 10 reais a peça. Sua duração é de 3 a 5 dias, que poderá ser prolongada se o produto for resfriado e se as pontas cortadas forem tratadas com cera ou outro produto antitranspirante e protetor contra fungos e bactérias. Possui aparência e cor atrativas, sabor suave, levemente adocicado, recomendado para o preparo do palmito assado na brasa (KAPP et al., 2003).

O palmito natural por apresentar baixa acidez $(\mathrm{pH} 5,6-6,2)$ pode ser facilmente contaminado por bactérias, fungos ou leveduras, e os alimentos mal manipulados servem como veículo de transmissão de infecções e intoxicações para o consumidor (ARAÚJO, 1993).

O palmito fresco ou minimamente processado é definido como o palmito comestível, após a extração das bainhas frescas de proteção; sempre haverá porções de estipe tenro e folhas tenras, ambos frescos. Os três estilos ou cortes (estipe tenro, palmito e folhas tenras) poderão ser oferecidos ao consumidor em bandejas diferentes, aplicando estes produtos a receitas culinárias também diferentes. Sugestões de receitas simples devem acompanhar o produto. Os toletes podem ser cortados em comprimento de 9 a $10 \mathrm{~cm}$ ou mais ou menos compridos. Estes toletes poderão ser tratados em soluções salinas (RAUPP, 2004; SOARES, 1997) ou cloradas (BELEGARD et al., 2005; JIMENEZ, 1992) para garantir sua assepsia antes de serem embalados. Os toletes poderão ser acondicionados em sacos plásticos ou em bandejas de isopor cobertos com filme plástico transparente. O palmito poderá ser conservado por 10 a 14 dias sob refrigeração $\left(10^{\circ} \mathrm{C}\right)$ e no escuro, o que é suficiente para comercialização perto do local de produção (MORA URPÍ, 1997).

Diversos produtores do sudeste estão colocando este tipo de produto nos supermercados. As bandejas são expostas, sob refrigeração e no claro, com tempo de prateleira de, no máximo, 5 dias. Este produto está disponível no Rio de Janeiro, São Paulo e em Honolulu e já possui demanda em Chicago, Washington, Nova York e Boston. Esta demanda será fácil de ser criada nos maiores supermercados do Brasil, pois o produto fresco conserva todo o atrativo do produto in natura e não é tão 
trabalhoso. Na cozinha, o palmito fresco pode ser cortado e servido, sem preparo prévio, em saladas, ou também, frito assado ou cozido em qualquer combinação e com qualquer acompanhamento. Os diferentes produtos atraem diferentes grupos étnicos (CLEMENT; BOVI, 2000).

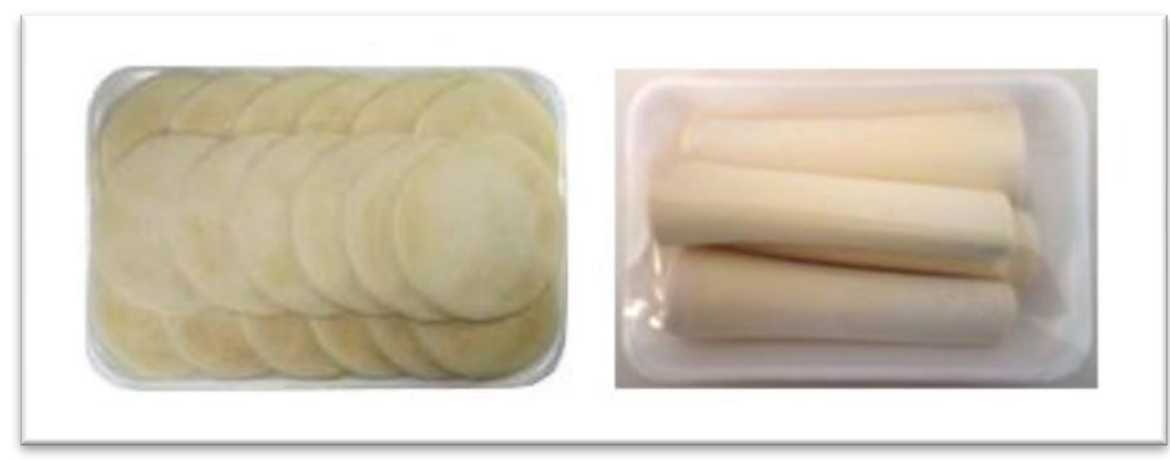

FIGURA 2. Bandejas de palmito pupunha minimamente processados, disponíveis no comércio.

Clement (1987) relata que a pupunha é um alimento quase completo, pois apresenta uma razoável quantidade de proteína, óleo, caroteno (pro-vitamina A) e amido. O valor energético do fruto da pupunha por apresentar uma proporção de $8,5 \%$ de açúcar e uma elevada taxa de gordura, assim sendo, possui um notável valor calórico, além de conter cálcio, ferro e vitaminas.

A tecnologia dos produtos minimamente processados, mesmo sendo mínima, produz destruição do tecido, por conseguinte, além de facilitar a contaminação microbiana, ocorre liberação de enzimas e de seus substratos, propiciando a ocorrência de reações enzimáticas que podem alterar as características sensoriais do produto. Em pesquisa conduzida por Clement et al. (1999), foi demonstrado que toletes de pupunha refrigerados minimamente processados (RMP) permaneceram apropriados ao consumo por um período de até 14 dias, quando conservados na temperatura de $10^{\circ} \mathrm{C}$. Apesar do uso já consagrado da tecnologia de processamento mínimo para alimentos vegetais, associados com o armazenamento sob refrigeração, ainda há carência de informações relacionadas com a aplicação dessa tecnologia para alguns produtos específicos, como o palmito de pupunha, que proporcionem maior confiabilidade quanto à segurança alimentar (MORETTI, 2001; WILEY, 1997; MACHADO, 2001). 


\subsubsection{Taxonomia}

- Família: Palmae (Arecaceae)

- Espécie: Bactris gasipaes Kunth

- Espécies relacionadas: no gênero Bactris são reconhecidas 73 espécies e 21 variedades que se distribuem desde o Sul do México e Caribe até o Sul do Brasil e Paraguai, com maior diversidade na Amazônia (HENDERSON, 2000).

- Nomes comuns: em Português (Brasil): pupunha, English: peach-palm (Trinidad and Tobago), peyibay(e), pejivalle; Spanish: pejibaye (Costa Rica, Nicaragua), chantaduro (Colombia, Ecuador), pijuayo (Peru), pijiguao (Venezuela), tembé (Bolivia), pibá (Panama), cachipay (Colombia).

\subsubsection{Morfologia e uso da pupunha}

A pupunheira apresenta grande variabilidade fenotípica. Esta variabilidade é mais visível no fruto; em geral a pupunheira da Amazônia Ocidental apresenta frutos maiores e contém maior teor de carboidratos, e a da Amazônia Oriental com frutos menores e maior teor de óleo. A pupunheira sem espinhos apresenta frutos maiores e ricos em carboidratos e vitamina A (YUYAMA, 2005).

Mesmo nos solos pobres, é possível cortá-la para extração do seu palmito por volta de dois anos. Quando as pupunheiras são adubadas, este período pode ser reduzido para um ano. Cada palmito pesa de 100 a 250 gramas. A pupunheira apresenta uma série de vantagens para produção de palmito em relação às outras palmeiras nativas como o açaí (Euterpe oleraceae Martius) e a juçara (Euterpe edulis Martius), que são exploradas de forma extrativista e por isso apresenta restrições legais e risco de extinção. Segundo Moro (1996), as principais vantagens para a exploração comercial de palmito da pupunheira são: a) precocidade, com o primeiro corte a partir de 18 meses após plantio; b) perfilhamento da planta mãe, o que permite repetir os cortes nos anos subsequientes, sem necessidade de replantio da área; c) qualidade do palmito, geralmente o palmito tem comprimento de $40 \mathrm{~cm}$ e diâmetro entre $1,5-4 \mathrm{~cm}$, sendo muito macio e saboroso; d) lucratividade, quando plantado e conduzido adequadamente, um hectare produz de 5.000 a 12.000 palmitos por ano; e) segurança para o produtor, 
pois o palmito pode ser deixado no pé ou quando cortado pode ser processado, envasado e guardado para ser comercializado quando o mercado se encontrar mais propício; f) facilidade nos tratos culturais e corte, uma vez que plantas selecionadas não apresentam espinhos (YUYAMA, 1999) e g) vantagens ecológicas, podendo a cultura ser conduzido a pleno sol, em áreas agrícolas tradicionais, sem nenhum dano às matas nativas, fato este de grande apelo comercial, principalmente para a exploração do palmito visando o mercado externo. Além disto, os frutos da pupunheira também podem ser aproveitados para a preparação de sucos, sorvetes e consumidos cozidos em água e sal (NISHIKAWA et al., 1998).

Tradicionalmente espécies locais de Bactris eram utilizadas como cultivo básico de sobrevivência, consumindo-se principalmente os frutos. De modo geral, todas as suas partes são aproveitadas: o tronco, como madeira para construções, arcos, flechas, arpões e varas de pescar; a raiz, como vermicida; as flores masculinas, como tempero; as folhas como matéria-prima para confecção de telhados, cestos e outros utensílios domésticos, além de servirem como forragem aos animais; o palmito como alimento; e os frutos, para extração de óleo e obtenção de farinha (BONACCINI, 1997).

A pupunha apresenta cinco utilizações básicas: fruto cozido, óleo, farinha, ração animal, palmito e tronco (BONACCINI, 1997; CHAIMSOHN, 2001):

- Fruto: Pode ser comido depois de cozido com sal por 30 a 60 minutos em panela de pressão. Também pode ser utilizado para fazer farinha para pão ou bolo, ou ainda ração para animais domésticos.

- Óleo: para cozimento e para alisar o cabelo.

- Farinha: a farinha é obtida a partir do cozimento dos frutos e é retirada da polpa, sem casca e sem caroço. A secagem é feita em fornos, semelhantes aos da farinha de mandioca, e posteriormente passa pelo processo de moagem. Segundo Clement (1987), é possível a substituição da farinha de trigo e milho pela farinha da pupunha. Na panificação, pode-se substituir até $10 \%$, sem alterações significativas no produto final. A relação fruto/farinha é de aproximadamente 4:1, ou seja, cada $400 \mathrm{~kg}$ de frutos produzem $100 \mathrm{~kg}$ de farinha. 
- Ração animal: para a sua elaboração podem-se utilizar três subprodutos da pupunha: a polpa (resíduo da extração do óleo), as folhas e as bainhas picadas. A polpa tem propriedades químicas semelhantes às do milho, podendo ser um substituto interessante nas áreas mais afastadas ou de pouca aptidão agrícola.

- Palmito: a pupunheira é cultivada para palmito no Sudeste do Brasil, especialmente no sul da Bahia, Espírito Santo, Rio de Janeiro, sul de Minas Gerais, sul de Mato Grosso do Sul, São Paulo e Paraná, bem como na Costa Rica e Equador. Pode ser consumido em conserva e como produto fresco. Além do palmito propriamente dito (palmito de primeira), cada estipe fornece dois outros produtos: o estipe tenro, obtido da parte logo abaixo do palmito e as folhas tenras não envolvidas numa bainha, obtidas da parte logo acima do palmito.

- Tronco: a madeira é preta, com linhas amarela muito bonita quando bem trabalhada, servindo para movelaria e artesanato.

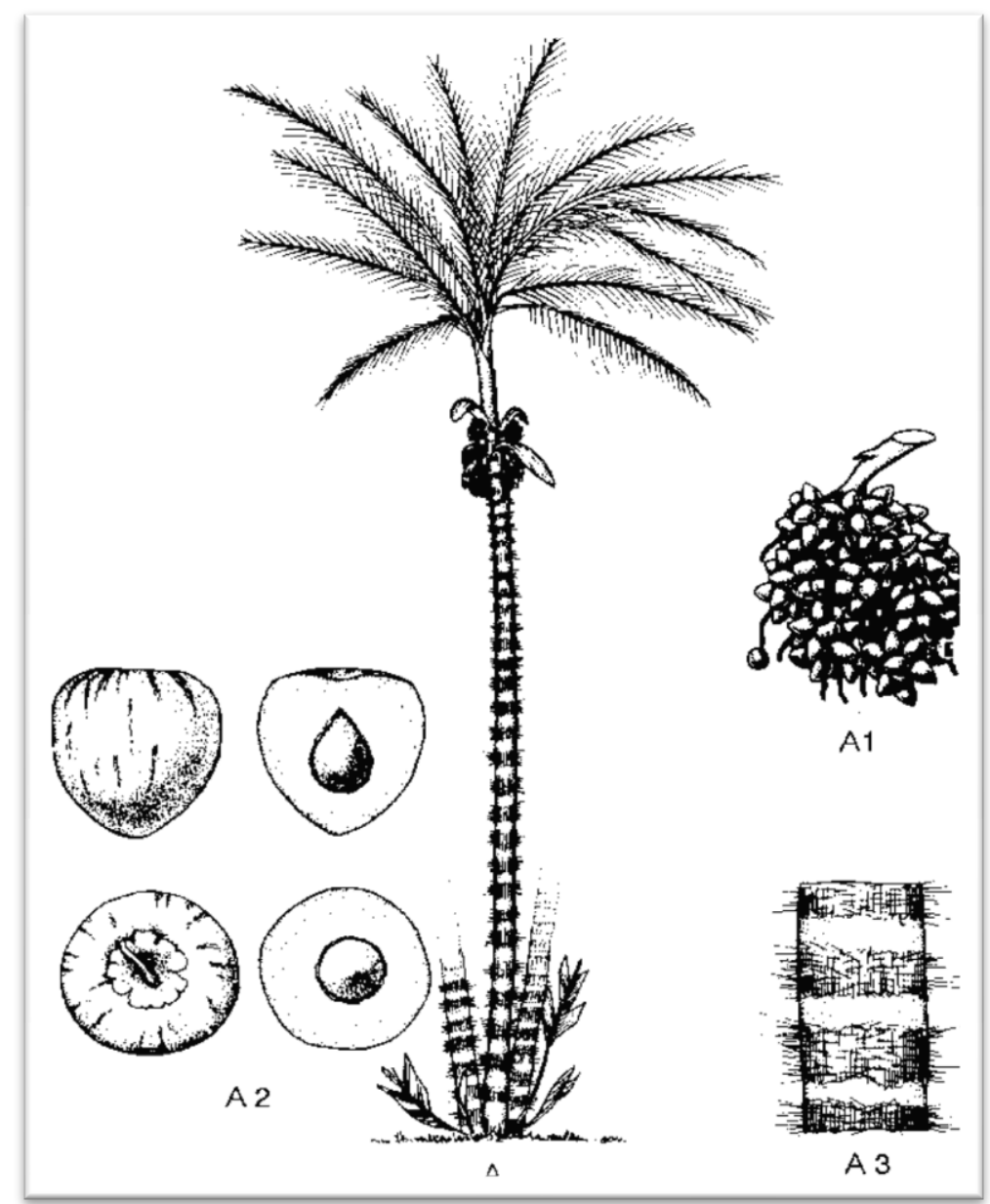

FIGURA 3. A) Palmeira de pupunha; A1) Cachos de frutos; A2) Seções transversais e perfil do fruto; A3) Coluna coberta de entrenós. 


\subsection{Irradiação de Alimentos}

A irradiação de alimentos é um método de conservação de alimentos que se desenvolve desde o início do século XX. Sua aplicação pode ser uma forma efetiva de reduzir a incidência de doenças alimentares e no tratamento de vários problemas potenciais em nossa cadeia de produção alimentar (LIMA et al, 2001).

Há mais de 100 anos, os cientistas da área da saúde pública têm se interessado pela irradiação de alimentos. Os primeiros experimentos ocorreram poucos anos após a descoberta dos raios-X pelo físico alemão Röentgen em 1895. A partir de 1914, cientistas franceses e alemães dedicaram-se aos estudos sobre alimentos pasteurizados através da radiação, mas estes possuíam paladar desagradável devido às altas doses empregadas. Em 1915, o raio X foi descrito como sendo efetivo sobre a destruição de cistos de Trichinella spp em carne de suínos. Mais tarde, o United States Department of Agriculture (USDA) provou que o raio X podia destruir organismos patogênicos e parar a esporulação no alimento (STEELE, 1999).

Organizações internacionais tais como a FAO (Organização de Alimento e de Agricultura das Nações Unidas), AIEA (Agência Internacional de Energia Atômica) e a OMS (Organização Mundial de Saúde) concluíram, após anos de pesquisas, que a irradiação de alimentos é um processo seguro e benéfico (DELINCÉE et al., 1998; FUMENTO, 1994; SPOLAORE et al., 2001; LOAHARANU, 1994).

Muito mais do que outros modernos processos de preservação de alimentos, a irradiação de alimentos teve que vencer barreiras criadas por informações erradas, prejudiciais, leis altamente restritivas e medidas regulatórias as quais até os dias atuais têm impedido o amplo uso desta tecnologia (DIEHL, 2002).

A irradiação de alimentos é um método simples e seguro para a preservação e armazenamento de alimentos em longo prazo, sendo uma alternativa mais atrativa e saudável, quando comparada aos tratamentos químicos, proibidos atualmente devido aos resíduos tóxicos (MARCHIONI, et al., 2005). Além disso, a irradiação de alimentos atende medidas de preservação ambiental, diminuindo gastos energéticos e riscos sanitários. 
A radiação ionizante penetra profundamente no alimento, reduzindo e/ou eliminando o número de microorganismos, sem elevar significamente à temperatura do produto. Portanto, é conhecida como esterilização a frio. É a forma de radiação escolhida para os alimentos porque, quando empregada de maneira correta, produz o efeito desejado com respeito ás características do produto, não induzindo radioatividade nos alimentos ou nas embalagens. Além disso, está disponível em quantidade e, seu custo permite o seu uso em escala comercial (FARKAS, 2006).

As radiações utilizadas no processamento de alimentos não possuem energia suficiente para provocar qualquer reação nuclear na matéria e, portanto, não deixam nenhum resíduo radioativo no material após a irradiação. Por esta razão, o alimento ou qualquer outro material submetido a esse tipo de radiação não se torna radioativo (MURANO et al, 1995).

Somente determinados tipos de radiações ionizantes possuem propriedades adequadas para o tratamento de alimentos. São radiações eletromagnéticas, em forma de raios gama ou de raios X. Os raios gama são radiações com comprimentos de onda que se originam na desintegração espontânea do núcleo atômico de certos elementos; os raios X são de igual natureza, porém são produzidos por geradores. Tanto os raios gama como os raios X são muito penetrantes e efetivos (FAO/IOEA/OMS, 1966).

A radiação mais utilizada no processo de conservação de alimentos é a do tipo gama (de isótopos radioativos de ${ }^{60} \mathrm{Co}$ ), mas também são utilizados em menor escala raios $\mathrm{X}$ e feixes de elétrons. Os raios gama e raios-X têm maior capacidade de penetração no alimento do que os feixes de elétrons, por isso o tratamento com aceleradores de elétrons somente é efetivo quando for levada em consideração a energia do equipamento, a espessura e a atividade de água do produto a ser irradiada, esta última deve ser considerada também na irradiação com raios gama e com raios-X. Nenhuma destas fontes de irradiação tem energia suficiente para ser capaz de induzir radioatividade no alimento, entretanto têm energia suficiente para remover elétrons dos átomos para formar íons ou radical livre. A quantidade de radiação ionizante absorvida é chamada de dose de radiação absorvida e é medida por unidade de Grays (1 Gy = 100 rads e $1 \mathrm{rad}=100 \mathrm{erg} / \mathrm{g}$ ), sendo $1 \mathrm{~Gy}$ o equivalente a 1 Joule/Kg e 1000 Grays equivalente a 1 kiloGray (kGy) (GAO, 2000; OLSON, 1998). 
Os raios gama e raios-X têm maior capacidade de penetração no alimento do que os elétrons, por isso o tratamento com aceleradores de elétrons somente é efetivo quando for levada em consideração a energia do equipamento, a espessura e a atividade de água do produto a ser irradiado, esta última deve ser considerada também na irradiação com raios gama e com raios-X (GAO, 2000; MINTIER \& FOLEY, 2006).

A diferença entre os feixes de elétrons e os raios gama emitidos por radionuclídeos não está só no poder de penetração destes, mas também na intensidade de energia da radiação. A radiação produzida pelos feixes de elétrons apresenta baixo poder de penetração, enquanto que a radiação gama oriunda do radioisótopo ${ }^{60}$ Co possui alta capacidade de penetração permitindo tratar produtos de diferentes tamanhos e formatos (DIEHL, 2002).

Os Íons e moléculas excitadas são as primeiras espécies formadas quando a radiação ionizante é absorvida por uma matriz alimentícia. O destino das moléculas excitadas é a dissociação em radicais livres. Entre as reações de íons pode-se citar a neutralização entre si e/ou a produção de novas moléculas excitadas podem por sua vez se dissociam em moléculas menores ou radicais livres. Os principais radicais livres formados pela radiólise são os radicais hidroxilas ( $\mathrm{OH}-)$ e o hidrogênio (H-), que são espécies muito reativas e instáveis e que podem combinar-se entre si em locais de altas concentrações de radicais ou podem se difundir no meio e reagir com outras moléculas dando prosseguimento à cadeia de oxidação (FENNEMA, 2007).

Os alimentos são tratados com radiação ionizante para alcançar diversos objetivos. Esta tecnologia de processamento dos alimentos pode aumentar a segurança dos alimentos pela redução dos níveis de bactérias patogênicas e outros microorganismos e parasitas causadores de doenças. A irradiação também inativa organismos daninhos dos alimentos, incluindo bactérias, mofos e leveduras. Pode ser eficaz na extensão da vida útil de frutas frescas e vegetais pela diminuição das mudanças biológicas normais associadas com os processos de crescimento e maturação, tais como brotamento e o amadurecimento. A radiação ionizante também se mostra promissora como um tratamento fitossanitário no controle de pestes, como parte de um programa de quarentena (MOREHOUSE, 2002). Células vegetativas são, no geral, mais sensíveis à radiação ionizante do que os esporos bacterianos e estes, por sua vez são 
menos resistentes do que os bolores e leveduras (DIEHL, 1995; MONK et al., 1995; ARAÚJO et a.l, 2009).

A irradiação deve ser aplicada em alimentos já embalados, porém não evita a recontaminação ou a re-infestação. A qualidade do alimento irradiado, bem como o de outro alimento, é função da qualidade do produto original. A radiação ionizante penetra profundamente no alimento, reduzindo e/ou eliminando o número de microorganismos, sem elevar significativamente a temperatura do produto. Portanto, é conhecida como esterilização a frio. É a forma de radiação escolhida para os alimentos porque, quando empregada de maneira correta, produz o efeito desejado com respeito às características do produto, não induzindo radioatividade nos alimentos ou nas embalagens. Além disso, está amplamente disponível e seu custo permite o seu uso em escala comercial (FARKAS, 2006).

A irradiação pode ser utilizada juntamente com outros métodos de conservação de alimentos como a refrigeração, tratamento térmico, cura e adição de substâncias químicas, a fim de prolongar, consideravelmente a vida útil de alguns alimentos durante o período de armazenamento, tanto refrigerado como não, sendo necessária uma embalagem adequada que não permita uma nova contaminação, uma vez que o alimento estará isento de qualquer flora microbiológica, desde que siga as boas práticas de fabricação (TRITSCH, 2000; MOREHOUSE, 2002).

É consenso que assim como para qualquer outra técnica de processamento de alimentos, é preciso um programa de controle de qualidade compatível com as Boas Práticas de Fabricação (BPF) ou outros sistemas que garantam a segurança alimentar (FERREIRA, 1999).

A qualidade nutricional dos alimentos irradiados é preservada, segundo conclusões do Grupo Consultivo Internacional sobre Irradiação de Alimentos (ICGFI, 1992), em relação aos seguintes aspectos:

- Conteúdo vitamínico, estabilidade e disponibilidade fisiológica; 
- Conteúdo qualitativo de gorduras, em especial a composição dos ácidos graxos essenciais;

- Digestibilidade dos componentes dos alimentos, como gorduras, hidratos de carbono e proteínas, mantendo a disponibilidade de energia biológica.

- Análise sensorial do alimento.

Mesmo eliminando os microrganismos dos alimentos deteriorados, a irradiação não pode eliminar os sinais externos de decomposição e, portanto não pode ser utilizada para "maquiar" alimentos deteriorados. Assim, a irradiação não difere do congelamento, da termo-pasteurização, etc., ou seja, deve-se somente irradiar (ou conservar) alimentos com boa qualidade higiênica (MALISKA, 2000; FAN \& SOKORAI, 2002).

Os custos para irradiação de alimentos variam de US\$10 a \$15 por tonelada para uma aplicação de baixa dose e de US\$100 a \$250 por tonelada para aplicação de altas doses (ICGFI, 1999).

\subsubsection{Legislação}

No Brasil, o decreto $n^{\circ} 72.718$ de 29/08/1973 estabelece e regulamenta a irradiação de alimentos e portarias complementares foram editadas em 1985 e 1989 . A Portaria $n^{\circ} 30$ de 02/08/89, da Divisão de Alimentos do Ministério da Saúde, indicava uma lista de produtos aprovados para irradiação e suas respectivas doses, determinava como dose limite 10kGy e proibida a re-irradiação. Em 26/01/2001, a Agencia Nacional de Vigilância Sanitária (ANVISA), aprovou a Resolução (RDC) n²1, que não restringem quais alimentos podem ser irradiados e nem a dose máxima absorvida para se obter o fim desejado, desde que não haja prejuízo nas suas qualidades funcionais e sensoriais (EMBRARAD, 2003).

Segundo a RDC $\mathrm{n}^{\circ} 21$, qualquer alimento pode ser irradiado desde que sejam observadas as seguintes condições: a dose mínima absorvida deve ser suficiente para alcançar a finalidade pretendida; a dose máxima absorvida de ser inferior àquela que comprometeria as propriedades funcionais e ou atributos sensoriais do alimento; a embalagem deve ter condições higiênicas aceitáveis para o processo de irradiação. 
A RDC n ${ }^{\circ} 21$ estabelece ainda que, quando um produto irradiado é usado como ingrediente em outro alimento, este fato deve ser indicado na embalagem final com o símbolo "radura" ou mencionando que o alimento foi tratado por irradiação.

Dentre os países que possuem legislação autorizando o uso da radiação em alimentos pode-se citar: Alemanha, Argentina, Bangladesh, Bélgica, Brasil, Canadá, Chile, China, Costa Rica, Croácia, Cuba, República Checa, Dinamarca, Finlândia, França, Hungria, Índia, Indonésia, Irã, Israel, Itália, Japão, Coréia, México, Holanda, Noruega, Paquistão, Filipinas, Polônia, Federação Russa, África do Sul, Espanha, Síria, Tailândia, Ucrânia, Reino Unido, Uruguai, EUA, Vietnã e Iugoslávia (IAEA, 2009).

\subsubsection{Alimentos minimamente processados}

Nos últimos anos tem sido enfatizado a necessidade de consumo de frutas e hortaliças frescas, buscando uma dieta mais saudável ao mesmo tempo em que há uma demanda crescente de alimentos mais convenientes, frescos, menos processados e prontos para o consumo. A indústria de alimentos tem respondido a essa demanda com

o desenvolvimento dos produtos minimamente processados (MP). Essa tecnologia emergente visa satisfazer a necessidade do consumo de frutas e hortaliças frescas, saudáveis e com qualidade nutricional, sensorial e microbiológica (VANETTI, 2000).

Wiley (1994) definiu os produtos minimamente processados como sendo aqueles preparados através de uma ou várias operações apropriadas, tais como descascamento, fatiamento, picamento e conservação através de tratamentos preservativos isolados ou combinados. Almeida (1998) aponta o processamento mínimo como uma série de operações para a obtenção de um produto que ofereça conveniência de uso e características semelhantes às do vegetal in natura. Hortaliças minimamente processadas são mais perecíveis do que quando intactas, porque são submetidas a severos estresses físicos advindos principalmente do descascamento e corte. Estes danos mecânicos aumentam o metabolismo dos produtos, com o conseqüente aumento da taxa de deterioração (FAN et al., 2003). 
A demanda de vegetais frescos cortados tem crescido devido às suas características de frescor e conveniência, entretanto a produção, a distribuição, a qualidade e a segurança de tais frutos e hortaliças são limitadas pelos conhecimentos que se têm acerca desse tipo de produto (BOLIN \& HUXSOLL, 1989).

$\mathrm{O}$ aumento da demanda por produtos minimamente processados traz consigo grandes desafios no que se refere ao desenvolvimento de tecnologias de armazenamento. Esses produtos apresentam maior taxa de deterioração do que o produto inteiro, considerando que, com o corte, os tecidos internos do vegetal são expostos e o metabolismo é acelerado. Adicionalmente, os tecidos ficam mais suscetíveis à contaminação microbiana, aumentando os riscos de toxinfecção alimentar, caso não sejam tomadas medidas preventivas (XUETONG FAN et al., 2005)

A durabilidade de um produto minimamente processado é extremamente baixa se comparada ao produto inteiro, considerando que nas superfícies do corte, as células e a membrana celular são destruídas e ocorre alteração no metabolismo celular. A injúria causada pelo corte promove aumento na produção de etileno e na taxa respiratória, favorecendo, assim, a rápida senescência. Mesmo os órgãos de reserva, como raízes, bulbos, rizomas e tubérculos, que naturalmente possuem uma vida pós-colheita relativamente longa quando submetidos ao processamento mínimo, passam a ser altamente perecíveis, com uma vida de prateleira muito curta (KASMIRE \& CANTWELL, 1992).

Para os vegetais frescos em geral, a contaminação por microrganismos patogênicos pode ocorrer em diferentes fases, desde a sua produção até o consumo. Na fase de produção agrícola, a contaminação pode ter origem no solo contaminado, na água de irrigação contaminada, no adubo orgânico, nos excrementos de animais (domésticos ou silvestres), entre outros. Na colheita e no processamento, a contaminação pode ocorrer de forma cruzada com os operadores, contêineres, equipamentos e durante o transporte. Já na fase de comercialização, os microrganismos presentes no vegetal embalado podem multiplicar-se e, dependendo do tempo e da temperatura de conservação, podem atingir níveis que comprometem a qualidade do produto e/ou a saúde do consumidor (BEUCHAT, 1996; NGUYEN-THE et al., 1994). 
Os alimentos minimamente processados são empacotados, depois de lavados geralmente com solução clorada, em embalagens permeáveis e embarcados/estocados sob refrigeração até o consumo. Como estes alimentos são freqüentemente consumidos como componentes de saladas, um risco de saúde pública pode estar associado a eles. Uma vez que a sanitização por meios químicos, como por exemplo, o tratamento com hipoclorito, não é muito confiável, assim como um empacotamento sob atmosfera modificada, que embora inibam a flora aeróbia contaminante podem promover o crescimento de patógenos anaeróbicos, há a necessidade de um procedimento que possa reduzir a incidência de microrganismos patogênicos associados aos alimentos frescos, sem alterar a sua característica de minimamente processados. (MARTINS et al., 2004).

\subsection{Análise sensorial}

Segundo definição da Associação Brasileira de Normas Técnicas a análise sensorial é a disciplina científica usada para evocar, medir, analisar e interpretar reações às características de alimentos e materiais percebidas pelos sentidos da visão, olfato, gosto, tato e audição (ABNT, 1995).

Através da análise sensorial pode-se determinar a aceitabilidade e a qualidade dos alimentos, com auxílio dos sentidos humanos como paladar e olfato. Para avaliar a qualidade; devem-se levar em conta as propriedades sensoriais aceitáveis, como essenciais no momento da venda e consumo do produto (MORALES, 1997).

A avaliação sensorial é efetuada de maneira científica, através de métodos sensoriais, que são utilizados para medir a qualidade dos alimentos através dos sentidos humanos de uma equipe de avaliação, especialmente treinadas para analisar os diferentes atributos destes (MONTEIRO, 1984; DUCCOSKY, 1996).

O odor, o sabor e a aparência são características fundamentais para a aceitação de um produto. Na indústria de alimentos a importância do odor está relacionada ao desenvolvimento de odores desejáveis, ao controle de odores indesejáveis bem como o uso de modificadores de odor. Devido à grande série de respostas olfativas há, 
provavelmente, mais problemas de odor do que de sabor, podendo os odores atrair ou repelir os consumidores. O sabor é definido como a sensação percebida na língua e na cavidade bucal. Quatro são as sensações básicas: ácido, salgado, doce e amargo. As outras sensações gustativas provêm da mistura dos quatro gostos básicos, em diferentes proporções causando variadas interações. No que diz respeito à aparência, o consumidor possui a expectativa de encontrar uma determinada cor para cada alimento e qualquer desvio desta cor pode produzir diminuição da aceitação do produto. Assim, muitos alimentos precisam ter sua cor intensificada para que possam ser mais ou menos apetitosos. Um alimento é primeiramente aceito ou rejeitado pela visão, ou seja, pela cor. Se a cor não for atraente, dificilmente o alimento será ingerido ou ao menos provado (MEILGAARD, 1991).

A análise sensorial é realizada em função das respostas transmitidas pelos indivíduos às várias sensações que se originam de reações fisiológicas e são resultantes de certos estímulos, gerando a interpretação das propriedades intrínsecas aos produtos. Para isto é preciso que haja interação entre as partes indivíduos e produtos, contato e interação. O estímulo é medido por processos físicos e químicos e as sensações por efeitos psicológicos. As sensações produzidas podem dimensionar a intensidade, extensão, duração, qualidade, gosto ou desgosto em relação ao produto avaliado (IAL, 2005).

A aparência de um alimento refere-se à propriedade visível como: cor (tonalidade, uniformidade, pureza); textura visual (brilhante, liso ou rugoso); tamanho e forma (fibroso, granuloso); características da superfície (aglomerado, solto) (ABNT, 1993; IAL, 2005).

A análise sensorial deve ser utilizada para avaliar atributos sensoriais de alimentos que sofreram processos de irradiação, paralelamente aos estudos microbiológicos e nutricionais (SOMMERS et al., 2004). Como toda tecnologia, a irradiação de alimentos apresenta limitações. Foi relatado, por exemplo, alterações sensoriais de odor, dependendo da dose de irradiação e da composição dos alimentos. É necessário então, encontrar um equilíbrio, para que a dose escolhida produza efeitos 
saudáveis necessários e preserve as características sensoriais dos alimentos (DESMONTS, 1997; BOSH, 2005).

Os cinco órgãos dos sentidos são as funções que permitem a captação das informações do mundo exterior, sendo eles a visão, audição, olfato, tato e sabor. A análise sensorial é realizada através do uso destes cinco sentidos, de forma a interpretar as respostas aos estímulos aplicados. O elemento humano é o instrumento que registra a medida, portanto uma equipe formada por um grupo de julgadores deve ser tratada como um instrumento científico. O odor, o sabor e a aparência são características fundamentais para a aceitação de um produto. Muitas vezes o que é significativo instrumentalmente e analiticamente, não é perceptível sensorialmente pelo consumidor. Por isso a importância de se realizar testes sensoriais para concluir uma pesquisa em que a opinião do consumidor é de extrema relevância (AMERINE et al, 1965; MEILGAARD, 1991).

A análise de variância, ANOVA é muito utilizada na comparação de dois ou mais tratamentos ou amostras em que se tem uma relação de causa e efeito entre os resultados obtidos, mas obriga os tratamentos serem independentes (FARIA et al., 2000). Esta análise permite estabelecer se as médias das populações em estudo são, ou não, estatisticamente diferente das demais. Assim, é realizada um comparação de médias dos distintos tratamentos com a amostra-controle utilizando o teste de Dunnett, estabelecendo-se uma significância ao nível de 5\% (O’MAHONY, 1986). 


\section{MATERIAL E MÉTODOS}

\subsection{Amostras}

As amostras de palmito pupunha foram cedidas por "Floresta Indústria e Comércio Ltda." localizada no Vale do Ribeira, Juquiá, São Paulo-SP. Amostras em tolete (inteiro / in natura) foram embaladas em plástico PVC e amostras de palmito minimamente processados foram divididas em partes: basal e nobre, embaladas em bandejas e envolvidas por plástico esticável.

A Floresta é uma empresa voltada para a produção de palmáceas, é uma agroindústria que além de não poluir o meio ambiente, contribui para o reflorestamento de áreas degradadas. Hoje ela define os requisitos para sistematização da gestão na segurança alimentar tanto no campo como na indústria, com cuidados desde a semente do palmito até o produto final in natura ou em conservas. Além disso, a Floresta é uma empresa que presa pela segurança e qualidade de seus produtos, trazendo assim a confiança do consumidor.

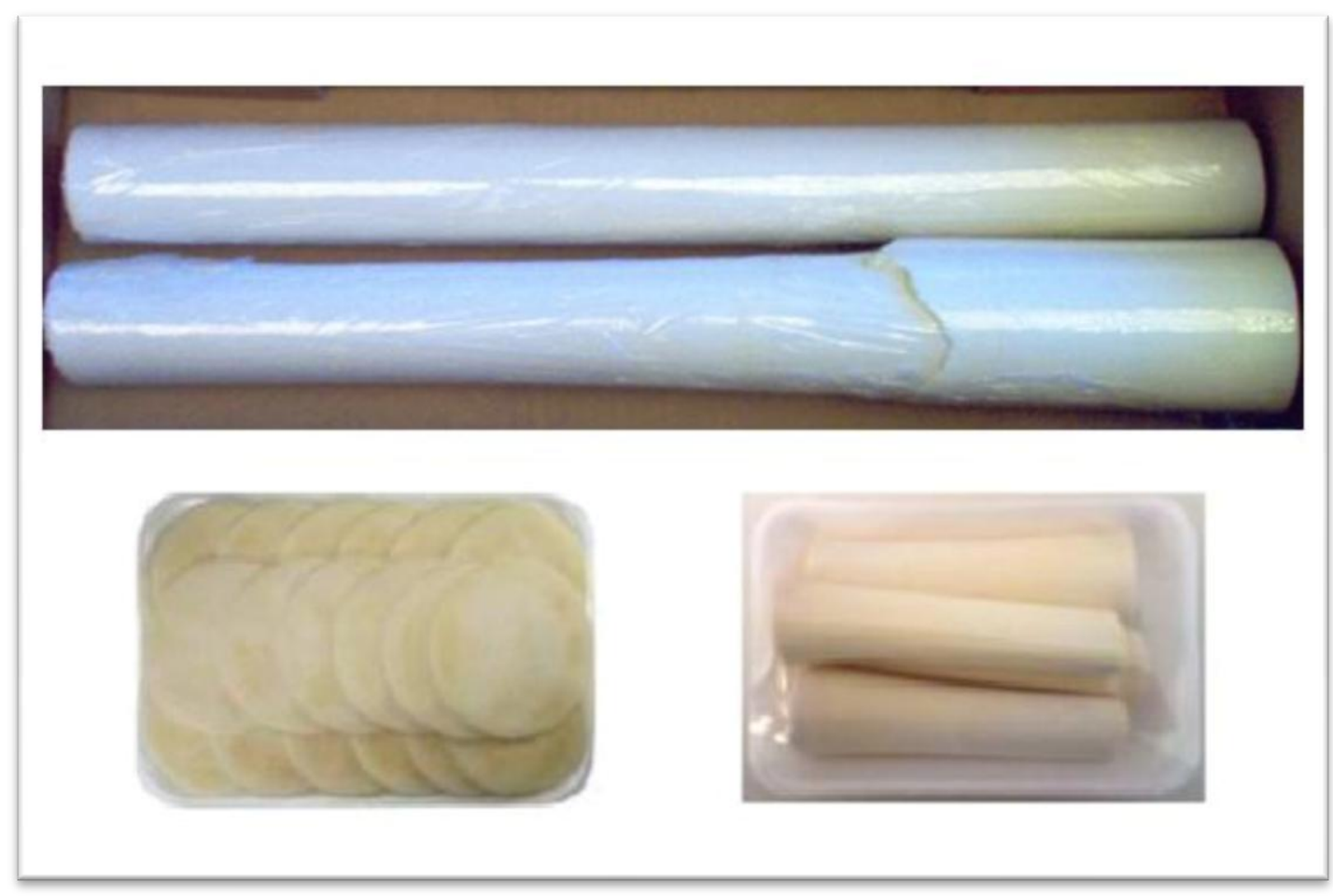

FIGURA 4. Amostras de palmito pupunha in natura (inteiro-tolete), e amostras da parte basal e nobre de palmito pupunha minimamente processado. 


\subsection{MÉTODOS}

\subsubsection{Irradiação}

As amostras de palmito pupunha foram irradiadas no Instituto de Pesquisas Energéticas e Nucleares (IPEN/CNEN-SP), Centro de Tecnologia das Radiações (CTR) num irradiador multipropósito de ${ }^{60} \mathrm{Co}$, com taxa de $5 \mathrm{kGy} / \mathrm{h}$, utilizando o dosímetro Gammachrome YR Lote 64 - 530mm para monitoramento da dose. Também foi utilizado um acelerador de elétrons (Radiation Dynamitron ${ }^{\mathrm{TM}}$ ) utilizando uma energia de 1,086 MeV, largura do feixe de $100 \mathrm{~cm}$ e velocidade da bandeja de $6,72 \mathrm{~m} / \mathrm{min}$ para ambas as doses utilizadas. A taxa de dose foi de 7,85 kGy/s e a corrente do feixe de 1,78 mA. A amostras foram irradiadas nas doses de 1 e 1,5 kGy em temperatura ambiente. Após a irradiação, as amostras foram armazenadas em câmera fria com temperatura de $8^{\circ} \mathrm{C}$.

\subsubsection{Preparação das amostras para o processamento de irradiação}

- Irradiador Multipropósito ${ }^{60} \mathbf{C o :}$ As amostras de palmito pupunha in natura (inteiro) foram embaladas em filme plástico PVC, armazenado em câmera fria com temperatura de $8^{\circ} \mathrm{C}$, durante 28dias. $\mathrm{O}$ mesmo procedimento foi utilizado para as amostras armazenadas em bandejas (parte basal e parte nobre).

- Acelerador de Elétrons: Foram utilizadas amostras da parte basal do palmito, embaladas e armazenadas em câmera fria com temperatura de $8^{\circ} \mathrm{C}$, durante 28dias.

\subsubsection{Tratamentos (Processos)}

\subsubsection{Irradiação no Multipropósito}

$11^{\circ}$ Processo: Foram colhidas as hastes (tolete) do palmito pupunha in natura, e foi dividido em 2 tratamentos: 
T1: Palmito in natura refrigerado à $8^{\circ} \mathrm{C}$.

T2: Irradiados nas doses de 1 e $1,5 \mathrm{kGy}$, e refrigerado à $8^{\circ} \mathrm{C}$.

$2^{\circ}$ Processo: Neste processo foi utilizado o palmito minimamente processado, bandejas de palmito em rodelas (parte basal) e inteiro (parte nobre), dividido em 2 tratamentos:

T1: Palmito refrigerado à $8^{\circ} \mathrm{C}$.

T2: Irradiados nas doses de 1 e $1,5 \mathrm{kGy}$, e refrigerado à $8^{\circ} \mathrm{C}$.

\subsubsection{Irradiação no Acelerador de Elétrons}

Amostras de palmito pupunha cortados em rodelas (parte basal), foram selecionadas com espessura de no máximo $4,5 \mathrm{~mm}$ de altura, embaladas em sacos plásticos. Precisou-se padronizar as amostras para que a penetração dos feixes de elétrons pudesse ultrapassar todo produto, garantindo a dose pretendida.

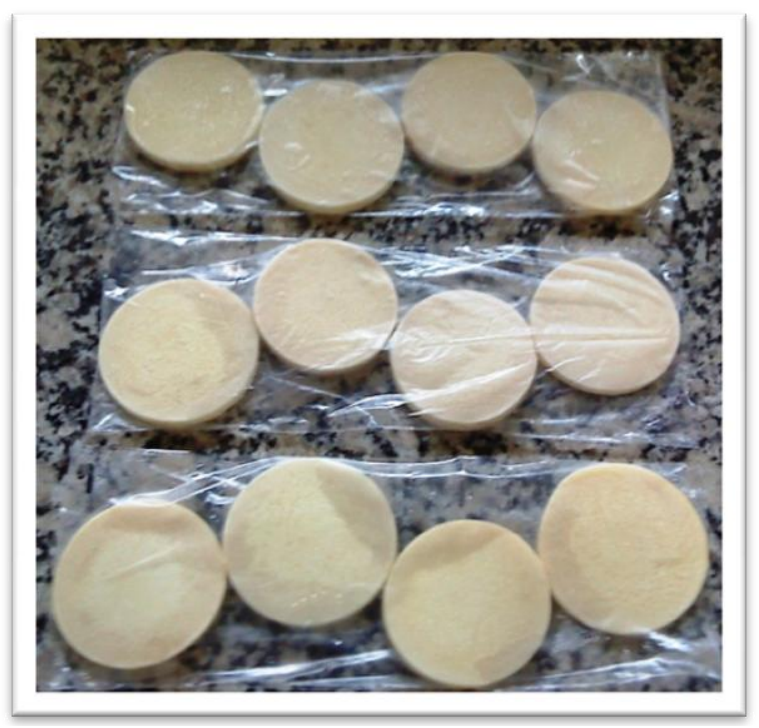

FIGURA 5. Amostras embaladas em sacos plásticos de palmito pupunha MP irradiados no acelerador de elétrons. 


\subsection{Análises Microbiológicas - Contagem de microrganismos aeróbios mesófilos (MORTON, 2001).}

As análises microbiológicas dos palmitos foram realizadas seguindo os procedimentos gerais (diluições, plaqueamento, repetições e contagens), realizada no Laboratório de Alimentos do Centro de Tecnologia das Radiações. Amostras de palmito foram divididas em 3 partes: basal, nobre e foliar. Porções de $25 \mathrm{~g}$ da amostra foram homogeneizadas com $225 \mathrm{~mL}$ de água peptonada (Merck) 0,1\% (acrescida de 0,85\% de $\mathrm{NaCl}$ ) e a partir desta primeira diluição (10-1) foram preparadas diluições decimais seriadas com o mesmo diluente. De cada diluição preparada, $1 \mathrm{~mL}$ foi transferido para uma placa de Petri estéril e adicionado $15 \mathrm{~mL}$ de ágar para contagem padrão (Difco), previamente fundido e resfriado. Após a homogeneização e solidificação do ágar, as placas foram incubadas em posição invertida a $30^{\circ} \mathrm{C}\left( \pm 1^{\circ} \mathrm{C}\right)$ por $48 \mathrm{~h}$. Após a incubação, foram contadas as placas com 30 a 300 colônias e aplicados os respectivos fatores de correção das diluições; os resultados foram expressos em médias e UFC/g.

\subsection{Análises de cor}

Para a realização desta análise, foram utilizadas amostras de palmito inteiro (tolete) e bandejas. A análise de cor foi avaliada através de um espectrofotômetro de bancada modelo Color Quest II (Hunter Lab) que analisa a cor do produto analogamente à análise realizada pelo olho humano. Essa análise é utilizada para a avaliação de cor de alimentos. O módulo de calibração utilizado foi reflectância especular excluída (RSEX), com uma fonte de iluminação D65 e ângulo visual de $10^{\circ}$. O sistema de leitura utilizado foi a Hunter $L, a, b$, que mede as três dimensões da cor, que representa o eixo da luminosidade, que vai de 0 (preto) a 100 (branco); a, que representa o eixo vermelhoverde (valores positivos são vermelho, valores negativos verde, e 0 é neutro); e b, que representa o eixo amarelo-azul (valores positivos são amarelo, valores negativos azul, e 0 é neutro). A metodologia utilizada está de acordo com a recomendação do fabricante do equipamento (HUNTERLAB, 1996). As leituras foram realizadas em amostras escolhidas aleatoriamente com 3 replicatas. 


\subsection{Textura}

A textura foi analisada pelo texturômetro TA-XT2 da marca Stable Micro Systems, operando com software Texture Expert, com modo e operação de força de compressão, com velocidade de teste de $1 \mathrm{~mm} / \mathrm{s}$. Utilizou-se um corpo de prova (probe) $\mathrm{P} / 2 \mathrm{~N}$ agulha de aço inox com espessura de $2 \mathrm{~mm}$, onde aplicou-se no centro do alimento. O parâmetro avaliado foi à força máxima de ruptura, obtido por meio do registro da curva força $\mathrm{x}$ tempo. As amostras de palmito foram retiradas da câmera fria $\mathrm{e}$ após meia hora foram realizadas as análises. Foram utilizadas 10 amostras de cada tratamento.

\subsection{Analise sensorial na indústria}

As análises foram realizadas na indústria "Floresta Indústria e Comércio Ltda", em Juquiá, São Paulo-SP.

Foram selecionados 12 provadores adultos com faixa etária de 20 à 50 anos, sem restrição de sexo, funcionários da empresa habituados ao consumo de palmito pupunha, que avaliaram a diferença global e a diferença de aparência entre as amostras de acordo com o teste de "Diferença do Controle" (MEILGAARD; 1999).

As amostras de palmito pupunha foram submetidas ao cozimento por 20 minutos e em seguida servidas em copos descartáveis transparentes de $100 \mathrm{~mL}$. Os provadores expressaram sua aceitação seguindo a escala previamente estabelecida que varia gradativamente, com base nos atributos muito melhor que o padrão a muito pior que o padrão (Figura 5). 


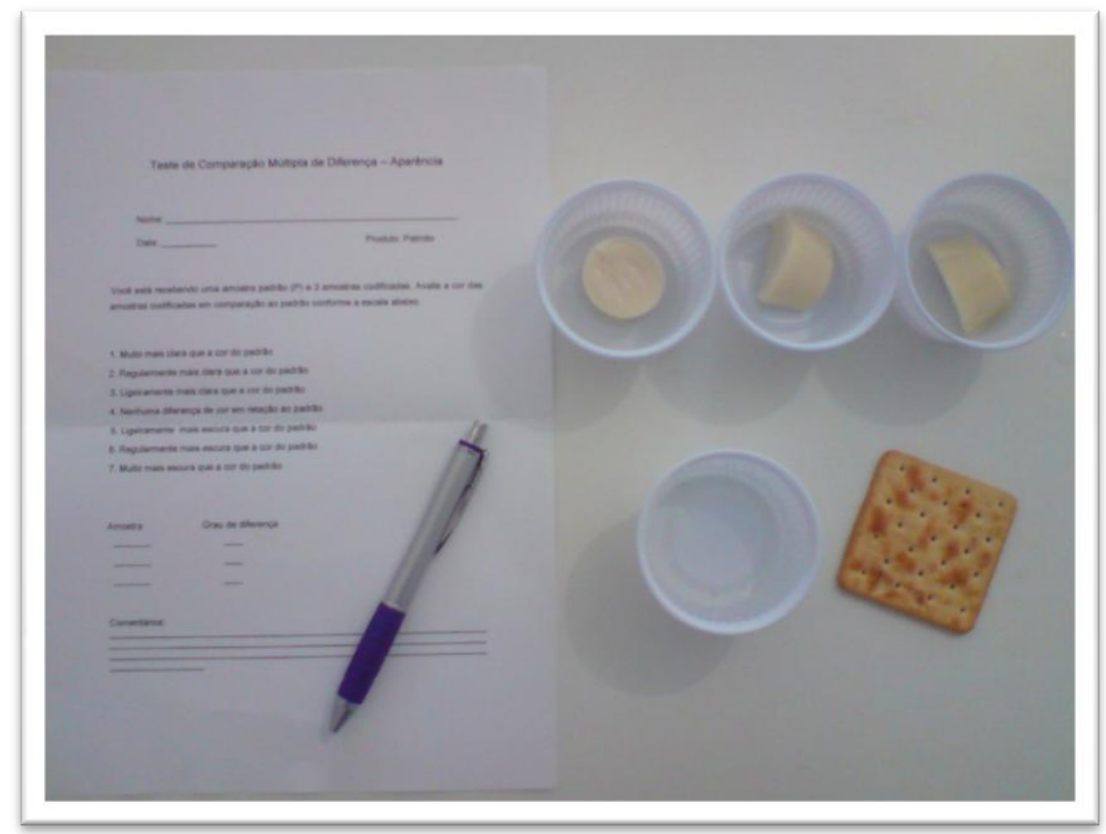

FIGURA 6. Ficha de avaliação sensorial e amostras apresentadas aos provadores.

\subsection{Análises Estatísticas}

Os resultados foram expressos em médias. Para comparação das médias aritméticas, empregaram-se a análise de variância (ANOVA) e o teste de Tukey usando o software Prisma 4,0 (GraphPad). Adotou-se o nível de significância de 5\% de probabilidade $(\mathrm{p}<0,05)$. Para análise estatística dos dados da análise sensorial foi realizada análise de variância (ANOVA), teste de Dunnet $(\mathrm{p}<0.05)$. 


\section{RESULTADOS E DISCUSSÃO}

\subsection{Microrganismos aeróbios mesófilos no palmito pupunha in natura irradiados}

no multipropósito com fonte de ${ }^{60} \mathrm{Co}$.

A contagem padrão de bactérias aeróbias mesófilas realizadas neste estudo teve por finalidade servir como indicador de qualidade higiênica dos produtos, fornecendo também uma idéia do tempo de vida útil de armazenamento. As amostras irradiadas de palmito pupunha in natura apresentaram diminuição na quantidade de bactérias aeróbias mesófilas presente nas amostras analisadas (tabela 1, figuras 7, 8 e 9).

TABELA 1. Resultados da análise microbiológica (média das contagens) obtidas de palmito pupunha in natura (parte: basal, nobre e foliar) processado no Multipropósito ${ }^{60}$ Co.

\begin{tabular}{lcccc}
\hline Amostras & $\begin{array}{c}\text { Tempo de } \\
\text { Armazenamento (Dias) }\end{array}$ & Controle & $\mathbf{1}$ kGy & $\mathbf{1 , 5}$ kGy \\
\hline \multirow{3}{*}{ Parte Basal } & 01 & $6,7 \times 10^{3}$ & $4,9 \times 10^{2}$ & $3,3 \times 10^{2}$ \\
& 07 & $7,1 \times 10^{3}$ & $5,1 \times 10^{2}$ & $4,5 \times 10^{2}$ \\
& 14 & $7,1 \times 10^{3}$ & $5,7 \times 10^{2}$ & $4,7 \times 10^{2}$ \\
& 21 & $7,7 \times 10^{3}$ & $6,4 \times 10^{2}$ & $4,8 \times 10^{2}$ \\
Parte Nobre & 28 & $8,2 \times 10^{3}$ & $6,8 \times 10^{2}$ & $5,3 \times 10^{2}$ \\
& 01 & $5,2 \times 10^{3}$ & $1,2 \times 10^{1}$ & $1,2 \times 10^{1}$ \\
& 07 & $5,9 \times 10^{3}$ & $1,5 \times 10^{1}$ & $1,4 \times 10^{1}$ \\
& 14 & $6,4 \times 10^{3}$ & $1,9 \times 10^{1}$ & $1,5 \times 10^{1}$ \\
& 21 & $6,5 \times 10^{3}$ & $2,2 \times 10^{1}$ & $1,5 \times 10^{1}$ \\
Parte Foliar & 28 & $7,3 \times 10^{3}$ & $2,7 \times 10^{1}$ & $1,9 \times 10^{1}$ \\
& 01 & $3,3 \times 10^{3}$ & $0,8 \times 10^{1}$ & $0,2 \times 101$ \\
& 07 & $4,5 \times 10^{3}$ & $1,4 \times 10^{1}$ & $0,4 \times 10^{1}$ \\
& 14 & $4,8 \times 10^{3}$ & $1,5 \times 10^{1}$ & $0,7 \times 10^{1}$ \\
& 21 & $5,7 \times 10^{3}$ & $1,9 \times 10^{1}$ & $1,2 \times 10^{1}$ \\
& 28 & $6,2 \times 10^{3}$ & $2,3 \times 10^{1}$ & $1,5 \times 10^{1}$ \\
\hline
\end{tabular}

* Unidade Formadora de Colônia por grama.

Nas análises microbiológicas, observamos que, conforme aumentamos a dose de radiação, a contagem de microrganismos decresce, este fato pode ser um indicador para a preservação do palmito irradiado e refrigerado, aumentando assim sua vida útil de prateleira. 


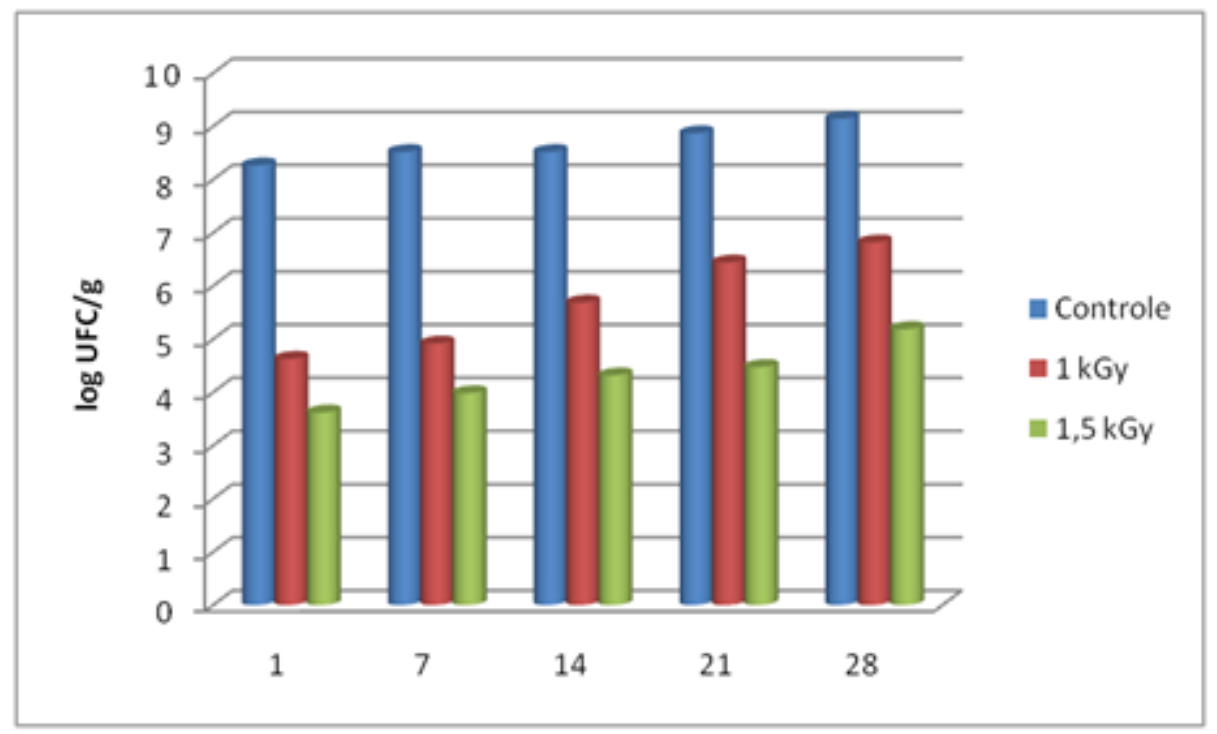

FIGURA 7. Contagens de microrganismos aeróbios mesófilos (média log UFC/g) presentes em amostras de palmito pupunha in natura (parte basal).

Segundo Franco \& Landgraf (1996), ainda que os patógenos estejam ausentes e que não tenham ocorrido alterações nas condições organolépticas do alimento, um número elevado de microrganismos aeróbios mesófilos (em geral superior a $10^{6} \mathrm{UFC} / \mathrm{g}$ ) e psicrotróficos pode indicar que o alimento é insalubre. Em alimentos perecíveis, esta condição pode ser indicativa de que ocorreu abuso durante o armazenamento em relação ao binômio tempo/temperatura. Vale ainda ressaltar, que todas as bactérias patogênicas de origem alimentar são mesófilas. Logo, elevadas populações destes microrganismos significa que houve condições para que estes patógenos se multiplicassem.

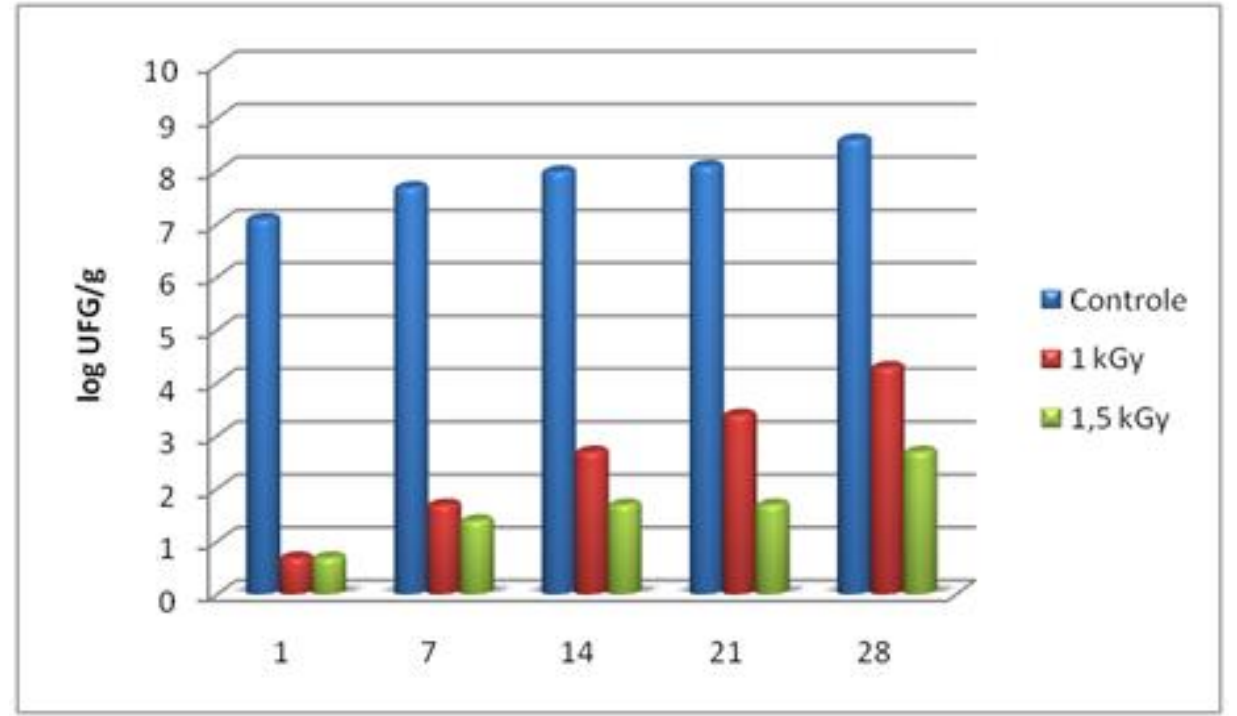

FIGURA 8. Contagens de microrganismos aeróbios mesófilos (média log UFC/g) presentes em amostras de palmito pupunha in natura (parte nobre). 


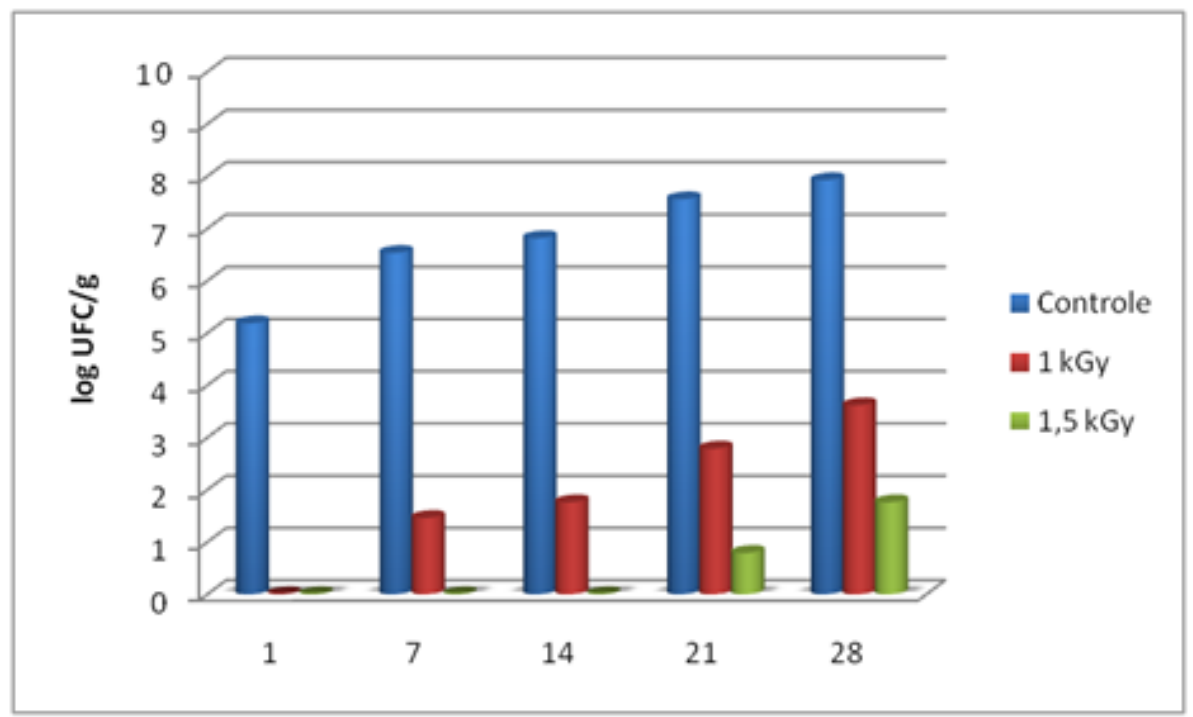

FIGURA 9. Contagens de microrganismos aeróbios mesófilos (média log UFC/g) presentes em amostras de palmito pupunha in natura (parte foliar).

A contagem total das bactérias aeróbias mesófilas aumentou com o decorrer dos dias de armazenamento para todos os tratamentos. As amostras de palmito pupunha in natura apresentaram as maiores contagens de bactérias em ambos os dias de análise.

Do ponto de vista da legislação vigente RDC n ${ }^{0} 12$ de 02 de Janeiro de 2001 da Agência Nacional de Vigilância Sanitária do Ministério da Saúde, as amostras de palmito pupunha in natura encontram-se de acordo com os valores permitidos.

\subsection{Microrganismos aeróbios mesófilos no palmito pupunha minimamente processado irradiado no multipropósito com fonte de ${ }^{60} \mathrm{Co}$.}

Os resultados das análises microbiológicas para bactérias mesófilas de palmito pupunha minimamente processados podem ser observados na tabela 2 .

Problemas microbianos podem surgir quando o efeito desejado não é alcançado e isso pode acontecer por erros nas técnicas de manipulação ou processamento. A detecção destes erros, sua rápida correção e prevenção futura são os maiores objetivos do controle microbiano, sendo responsabilidade de todos os indivíduos envolvidos nas 
diferentes etapas da cadeia alimentar, desde a fazenda até o consumidor final (MASIH et al., 2001).

TABELA 2. Resultados da análise microbiológica (média das contagens) obtidas de palmito pupunha MP (parte: basal, nobre e foliar) processado no Multipropósito ${ }^{60} \mathrm{Co}$.

\begin{tabular}{|c|c|c|c|c|}
\hline \multirow[t]{2}{*}{ Amostras } & \multirow{2}{*}{$\begin{array}{c}\text { Tempo de } \\
\text { Armazenamento (Dias) }\end{array}$} & \multicolumn{3}{|c|}{ UFC/g de microrganismos aeróbios mesófilos } \\
\hline & & Controle & 1 kGy & $1,5 \mathrm{kGy}$ \\
\hline \multirow{5}{*}{ Parte Basal } & 01 & $3,7 \times 10^{3}$ & $2,9 \times 10^{2}$ & $1,3 \times 10^{2}$ \\
\hline & 07 & $5,1 \times 10^{3}$ & $4,1 \times 10^{2}$ & $2,5 \times 10^{2}$ \\
\hline & 14 & $5,6 \times 10^{3}$ & $5,7 \times 10^{2}$ & $2,7 \times 10^{2}$ \\
\hline & 21 & $6,7 \times 10^{3}$ & $5,7 \times 10^{2}$ & $3,3 \times 10^{2}$ \\
\hline & 28 & $7,3 \times 10^{3}$ & $6,2 \times 10^{2}$ & $3,5 \times 10^{2}$ \\
\hline \multirow{5}{*}{ Parte Nobre } & 01 & $2,6 \times 10^{3}$ & $1,2 \times 101$ & $0,2 \times 10^{1}$ \\
\hline & 07 & $3,6 \times 10^{3}$ & $1,5 \times 101$ & $0,7 \times 10^{1}$ \\
\hline & 14 & $3,4 \times 10^{3}$ & $1,9 \times 10^{1}$ & $1,2 \times 10^{1}$ \\
\hline & 21 & $4,1 \times 10^{3}$ & $2,2 \times 10^{1}$ & $1,3 \times 10^{1}$ \\
\hline & 28 & $4,4 \times 10^{3}$ & $2,7 \times 10^{1}$ & $1,3 \times 10^{1}$ \\
\hline \multirow{5}{*}{ Parte Foliar } & 01 & $5,3 \times 10^{2}$ & $0,8 \times 10^{1}$ & ND \\
\hline & 07 & $6,5 \times 10^{2}$ & $1,4 \times 10^{1}$ & ND \\
\hline & 14 & $6,8 \times 10^{2}$ & $1,5 \times 10^{1}$ & ND \\
\hline & 21 & $7,7 \times 10^{2}$ & $1,9 \times 10^{1}$ & ND \\
\hline & 28 & $8,2 \times 10^{2}$ & $2,3 \times 10^{2}$ & ND \\
\hline
\end{tabular}

* Unidade Formadora de Colônia por grama

ND - Não Detectado

Conforme verificado no presente experimento, ocorreu um aumento gradativo no número de bactérias, com exceção da parte foliar com a dose de 1,5 kGy, onde não se observou crescimento microbiano (Figuras 10, 11 e 12). Essa diminuição esta relacionada com a sanitização que tem como objetivo reduzir a população microbiana presente no processo de industrialização e na superfície do produto processado. Nas amostras analisadas podemos ressaltar que a sanitização está sendo eficiente, pois a população microbiana está de acordo com o tolerado pela legislação.

A desinfecção de frutas e vegetais prolonga a vida útil e reduz o risco de causar uma toxiinfecção, diminuindo o número de microrganismos na superfície do alimento (PELCZAR et al, 1997). 


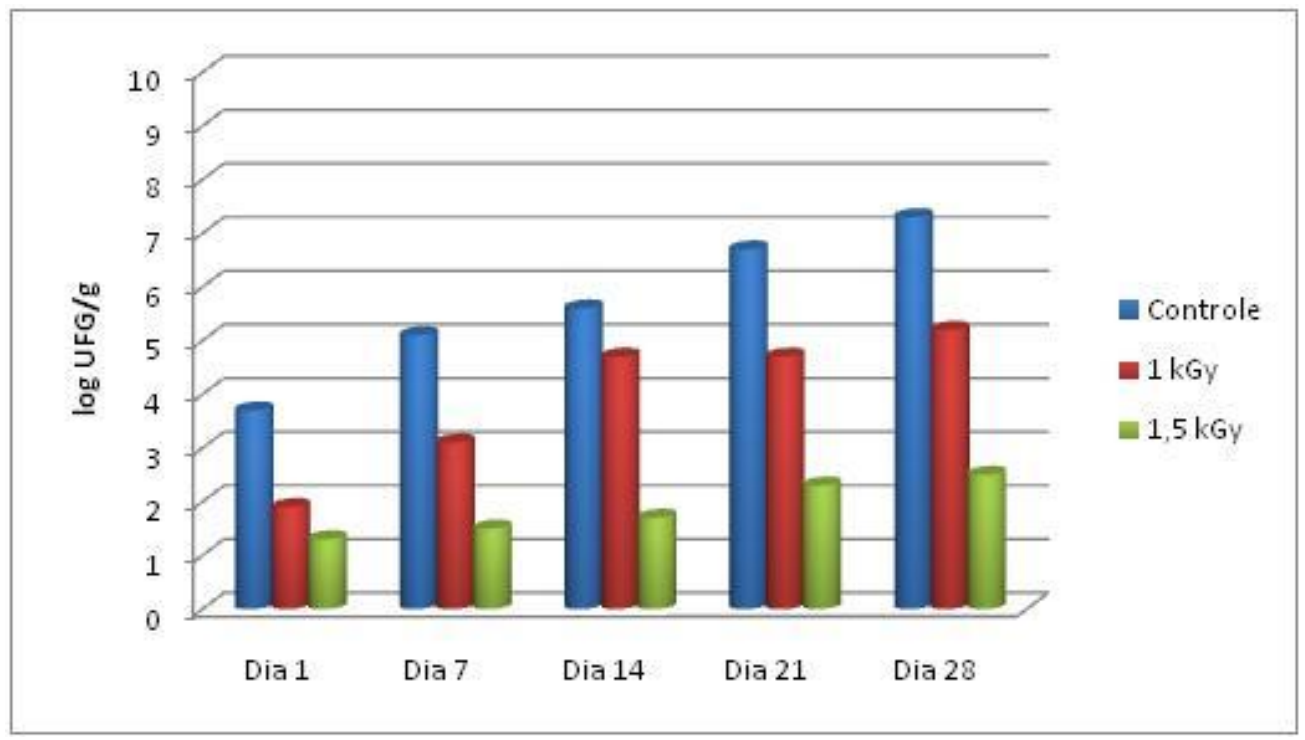

FIGURA 10. Bactérias aeróbias mesófilas de palmito pupunha minimamente processado (sanitizado) irradiado no multipropósito com fonte de ${ }^{60} \mathrm{Co}$ (parte basal).

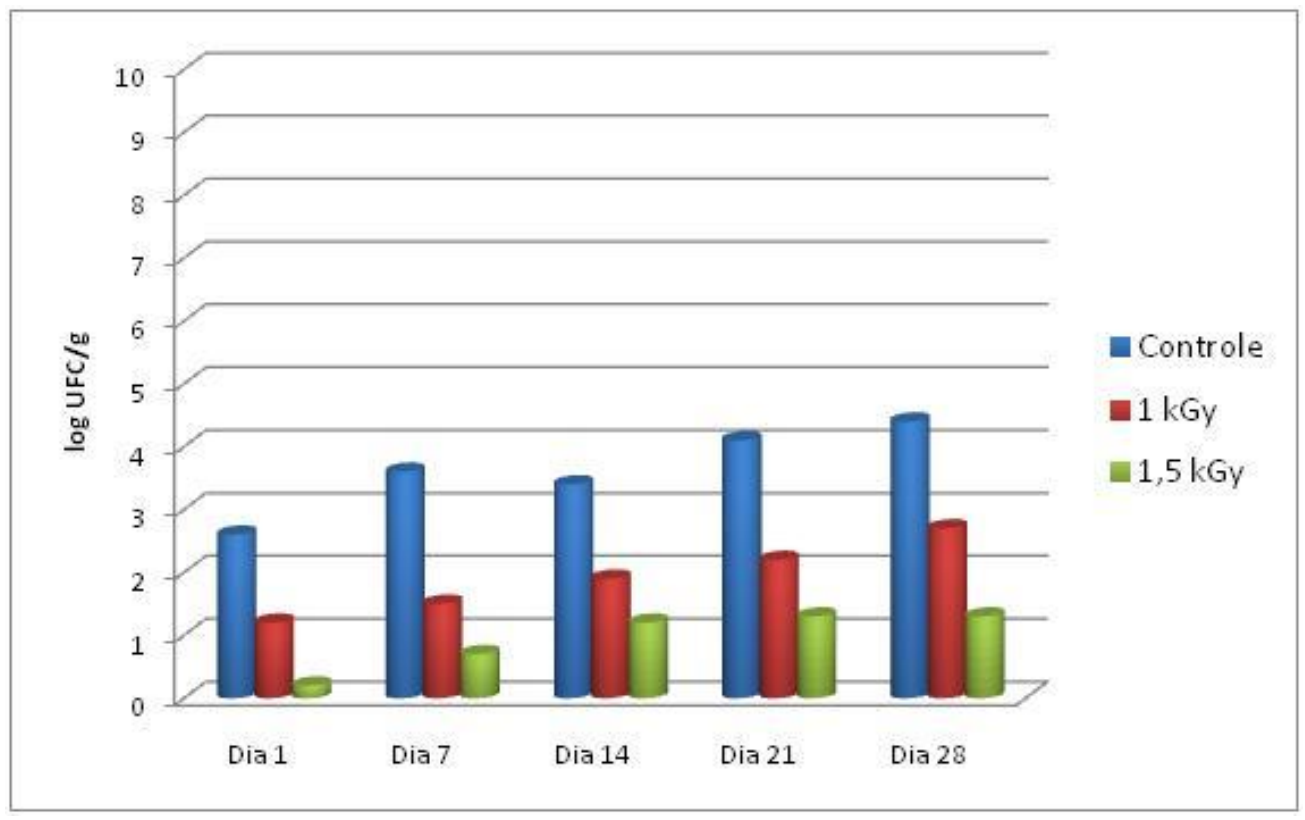

FIGURA 11. Bactérias aeróbias mesófilas de palmito pupunha minimamente processado (sanitizado) irradiado no multipropósito com fonte de ${ }^{60} \mathrm{Co}$ (parte nobre). 


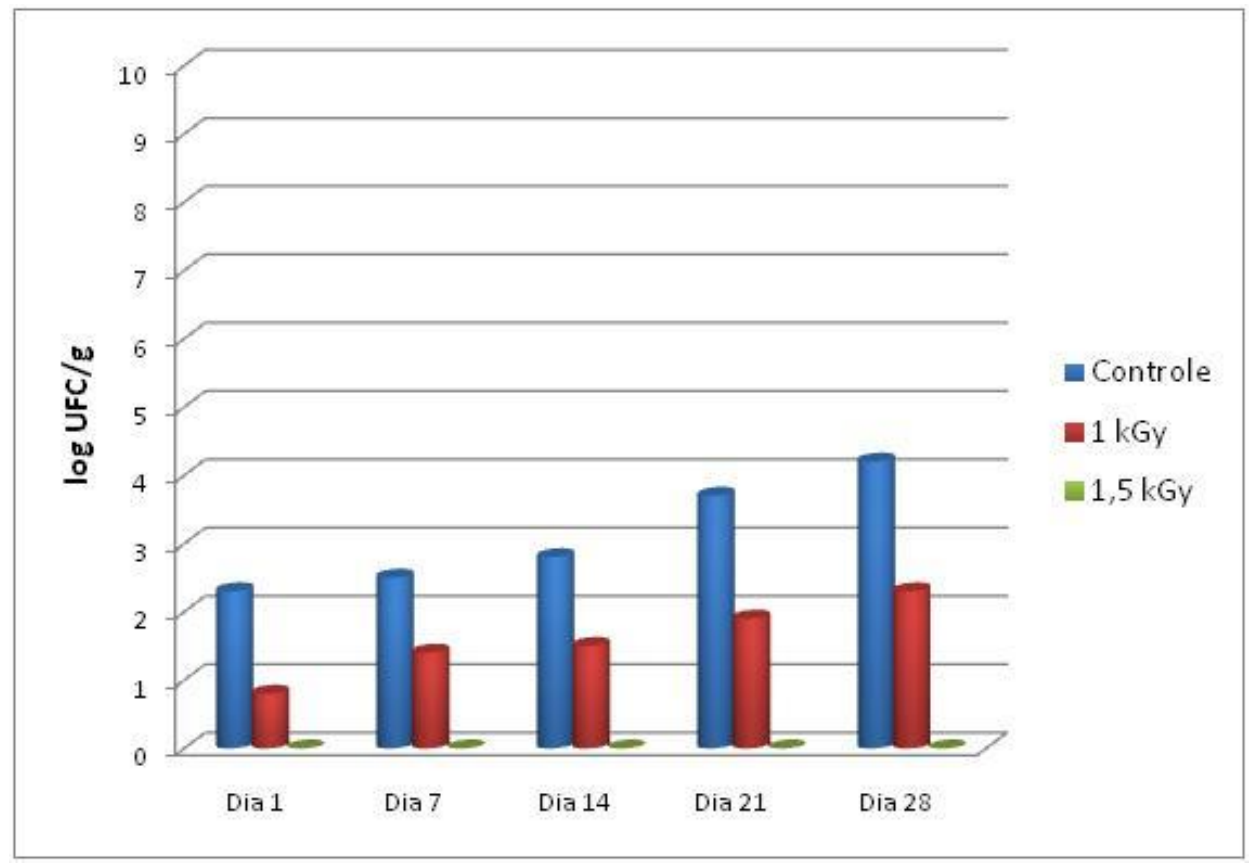

FIGURA 12. Bactérias aeróbias mesófilas de palmito pupunha minimamente processado (sanitizado) irradiado no multipropósito com fonte de ${ }^{60} \mathrm{Co}$ (parte nobre).

Para produtos minimamente processados, ainda não existe uma legislação determinando os limites de contagens permitidas. Entretanto, estes resultados estão de acordo com a resolução $\mathrm{RDC} \mathrm{n}^{0} 12$.

Mesmo que sejam adotadas boas práticas agrícolas (BPA), o risco de infecções ou intoxicações pode ocorrer durante o processamento, à distribuição e a preparação do alimento devido á manipulação do mesmo (JAY, 1998).

Em estudo Berbari et al, 2008 analisou palmito das palmeiras açaí, pupunha e real australiana em conserva, e obteve como resultados de análise microbiológica ausência de microrganismos mesófilos e termófilos acidotolerantes, bolores e leveduras, ou seja, as amostras encontraram-se de acordo com os padrões microbiológicos, sendo consideradas comercialmente estéreis. Vale ressaltar que as amostras em conserva estão menos suscetíveis a estes tipos de contaminação levando em conta o processo de industrialização. 


\subsection{Microrganismos aeróbios mesófilos no palmito pupunha (parte basal) MP submetidos á radiação ionizante por Acelerador de Elétrons.}

A dose de radiação necessária para controlar microrganismos em alimentos depende de diversos fatores, como a resistência particular de cada espécie e o grau de contaminação do alimento (FARKAS, 2006). Normalmente para vegetais aplica-se baixas doses de radiação, visando a redução de número de microrganismos deteriorantes e o prolongamento de sua vida útil e qualidade sensoriais.

No presente trabalho observamos na tabela 3 que as amostras de palmito pupunha (parte basal) estão com mais contaminação microbiana do que as amostras analisadas processados por radiação gama de ${ }^{60} \mathrm{Co}$. Considerando o processamento mínimo por si só não reduz os níveis de microrganismos patogênicos a patamares seguros, o processamento por irradiação pode aumentar a segurança do consumidor.

TABELA 3. Número de microrganismos aeróbios mesófilos (*UFC/g) no palmito pupunha minimamente processado (parte basal) após o processamento do produto por feixes de elétrons.

\begin{tabular}{ccccc}
\hline Amostras & $\begin{array}{c}\text { Tempo de } \\
\text { Armazenamento (Dias) }\end{array}$ & \multicolumn{3}{c}{$*$ UFC/g microrganismos aeróbios mesófilos } \\
& Controle & $\mathbf{1 ~ k G y}$ & $\mathbf{1 , 5}$ kGy \\
\hline \multirow{6}{*}{ Parte Basal } & 01 & $4,4 \times 10^{3}$ & $3,9 \times 10^{2}$ & $1,3 \times 10^{2}$ \\
& 07 & $5,1 \times 10^{3}$ & $4,1 \times 10^{2}$ & $2,5 \times 10^{2}$ \\
& 14 & $5,6 \times 10^{3}$ & $4,7 \times 10^{2}$ & $2,5 \times 10^{2}$ \\
& 21 & $6,7 \times 10^{3}$ & $5,5 \times 10^{2}$ & $3,3 \times 10^{2}$ \\
& 28 & $6,3 \times 10^{3}$ & $6,2 \times 10^{2}$ & $4,5 \times 10^{2}$ \\
\hline
\end{tabular}

Conforme esperado o tempo de armazenamento influenciou no crescimento microbiano, a cada semana que se realizava as análises, a quantidade de microrganismos aumentava, e ao final das análises, com 28 dias de armazenamento observamos a degradação do alimento, tornando-se impróprio para o consumo (figura 13). 


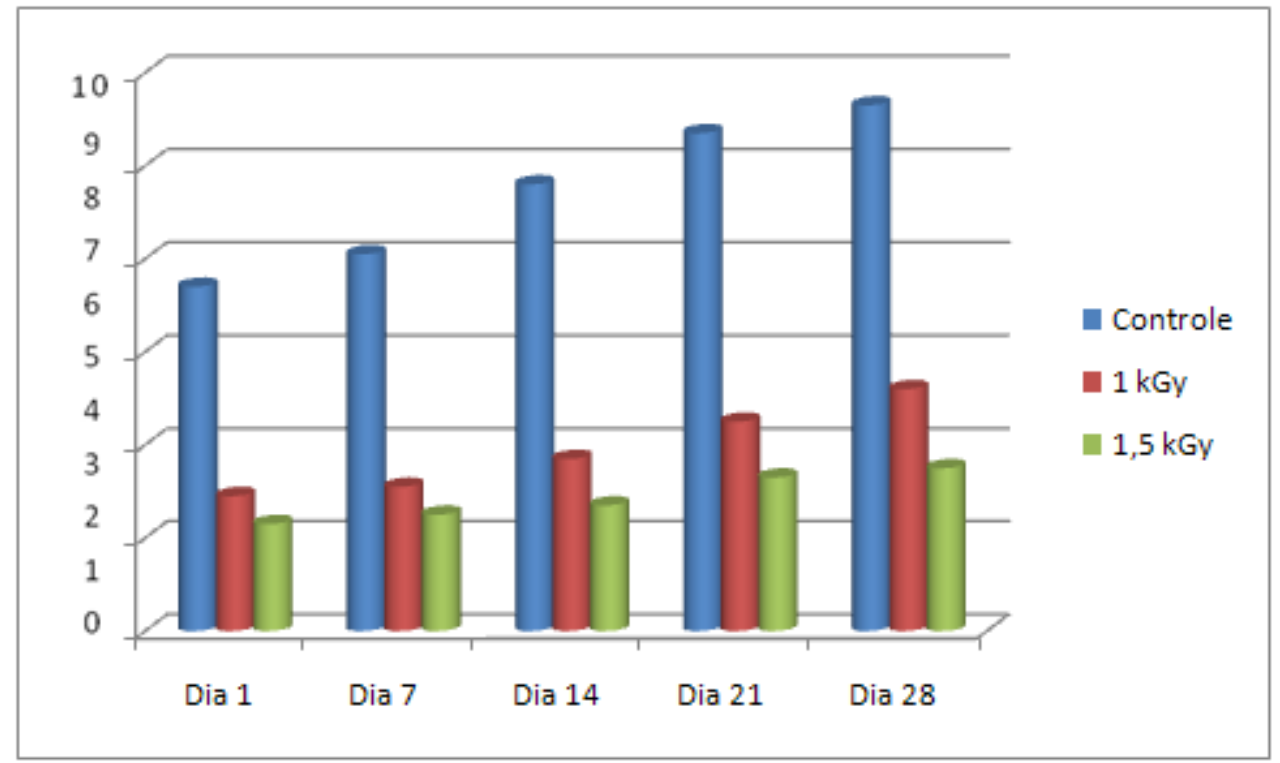

FIGURA 13. Contagens de microrganismos aeróbios mesófilos (média log UFC/g) presentes em amostras de palmito pupunha minimamente processado (parte basal).

Esta claro que, bactérias podem se multiplicar depois do processamento por radiação, e podem atingir o mesmo número de microrganismos da população inicial se forem estocados em temperatura abusiva ou por tempo prolongado.

\section{Análises de Cor - Amostras de palmito pupunha in natura irradiadas em Multipropósito com fonte de ${ }^{60} \mathrm{Co}$.}

A aparência é uma característica sensorial do alimento, composta de cor, brilho, tamanho e forma, sendo mais marcante o impacto visual causado pela cor. A cor está relacionada com a qualidade dos alimentos frescos, constituindo-se como o primeiro critério aplicado para sua aceitação ou rejeição (DELLA, 1994).

O parâmetro $L$ dá a medida de luminosidade do produto e vai de 0 , para totalmente preto, até 100, para totalmente branco. As escalas vermelho/verde e amarelo/azul são representadas pelos parâmetros $a$ e $b$, respectivamente. Valores positivos do parâmetro a indicam presença da cor vermelha, enquanto negativos representam presença da cor verde. O equivalente ocorre para valores positivos e negativos de b indicando presença das cores amarelo e azul, respectivamente. Valores nulos desses parâmetros indicam ausência dessas cores (HUNTERLAB, 1996). 
Os resultados da cor de palmito pupunha in natura estão apresentados na forma de tabelas e figuras, a fim de ser observada a influência do tempo sobre a luminosidade $(L)$, figura 14 e sobre os valores de $a$ e $b$, figuras 15 e 16 .

A tabela 4 mostra as médias dos parâmetros $L, a$ e $b$ de amostras de palmito pupunha in natura armazenados sob refrigeração de $8^{\circ} \mathrm{C}$ e irradiados nas doses de $1 \mathrm{e}$ 1,5 kGy e também a amostra controle.

TABELA 4. Médias dos parâmetros $L, a$ e $b$ de palmito pupunha in natura.

\begin{tabular}{lcccc}
\hline & Dia 1 & Dia 7 & Dia 14 & Dia 21 \\
Valor $\boldsymbol{L}$ & & & & \\
Controle & 87,1 & 86,4 & 86,2 & 85,9 \\
1 kGy & 85,8 & 85,2 & 84,9 & 84,1 \\
1,5 kGy & 85,1 & 84,4 & 84,2 & 83,9 \\
& & & & \\
Valor de $\boldsymbol{a}$ & & & & \\
Controle & $-0,78$ & $-0,78$ & $-0,81$ & $-0,85$ \\
1 kGy & $-0,81$ & $-0,83$ & $-0,83$ & $-0,89$ \\
1,5 kGy & $-0,84$ & $-0,87$ & $-0,86$ & $-0,91$ \\
& & & & \\
Valor de $\boldsymbol{b}$ & & & & 13,8 \\
& & & 13,83 & 14,11 \\
Controle & 13,74 & 13,76 & 14,04 & 16,17 \\
1 kGy & 13,92 & 13,99 & 15,97 & \\
1,5 kGy & 15,28 & 15,66 & & \\
\hline
\end{tabular}

De acordo com os resultados apresentados na figura 14, observa-se que os valores de $L$ são próximos de 100, indicando alta luminosidade, ou seja, que as amostras de palmito pupunha estão predominantemente claro. Observamos também que as amostras irradiadas escureceram mais do que as amostras controle ao longo do período de armazenamento. 


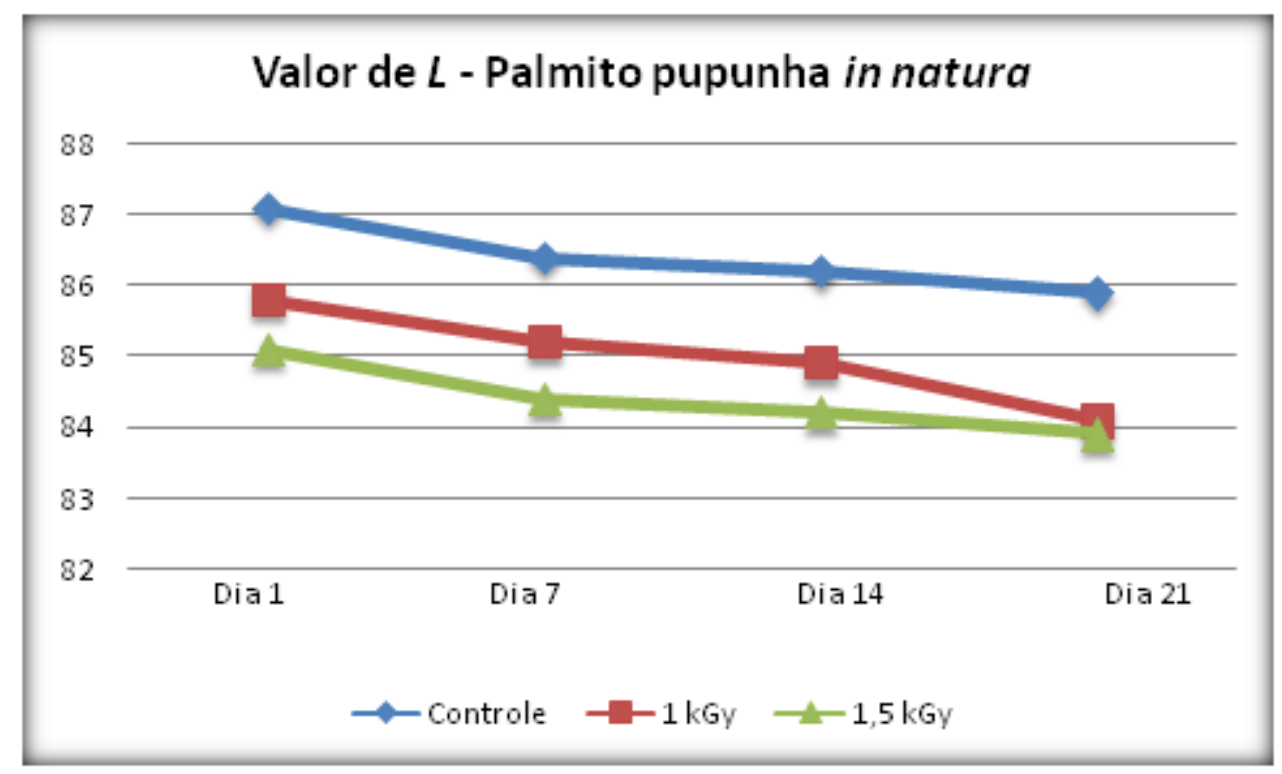

FIGURA 14. Parâmetro $L$ (Luminosidade) para amostras de palmito pupunha in natura submetidas ao processo de radiação gama nas doses de 1 e 1,5 kGy armazenadas em diferentes períodos (valores médios).

Observamos na figura 15 os valores do parâmetro $a$ mostra que ao longo do período de armazenamento indicou que a amostra irradiada apresentou tons de verde. Visualmente essa tonalidade pode ser observada a partir do período de 14 dias.

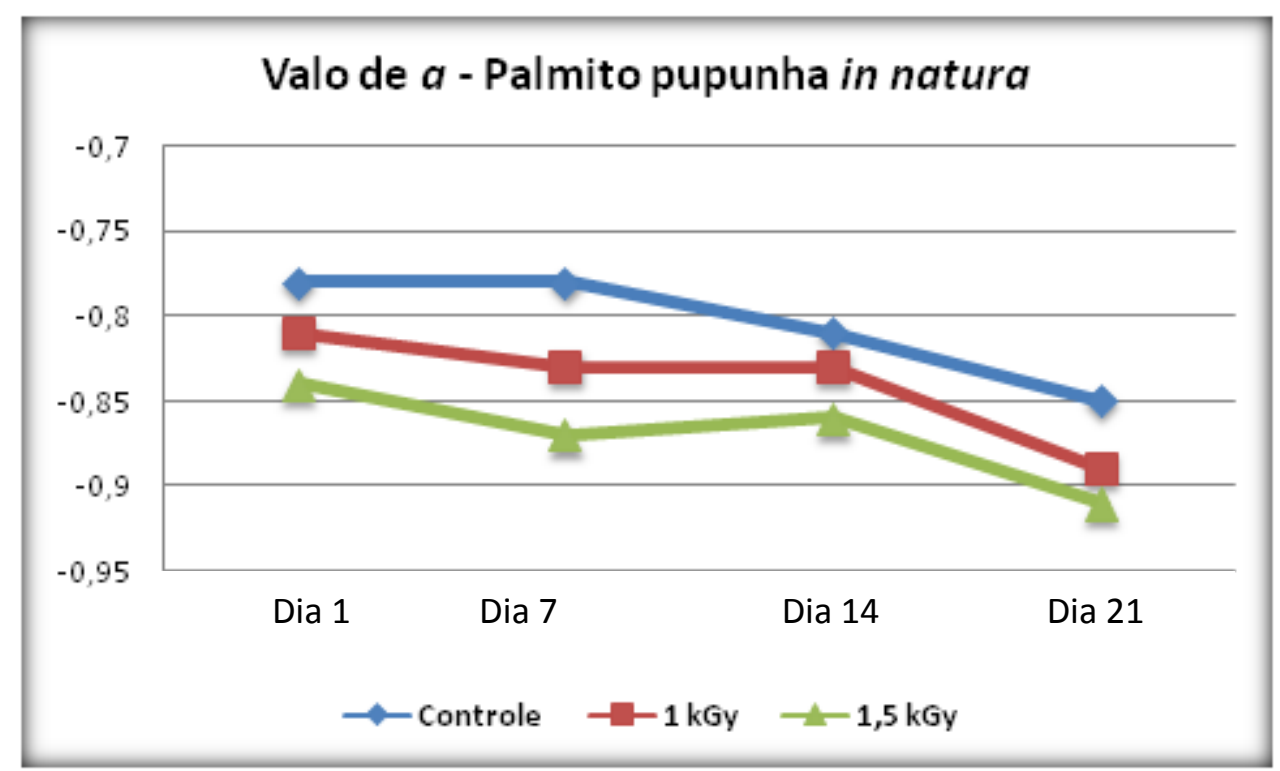

FIGURA 15. Fator $a$ (+a: vermelho, -a: verde) para amostras de palmito pupunha in natura submetidas ao processo de radiação gama nas doses de 1 e 1,5 kGy armazenadas em diferentes períodos (valores médios). 
A figura 16 mostra as médias dos valores obtidos no parâmetro $b$, observamos que as amostras se diferenciaram entre si, principalmente a amostra irradiada com 1,5 kGy que ficou com um tom mais amarelado $(+b)$ no decorrer do período de armazenamento, enquanto as demais amostras não perderam suas características naturais.

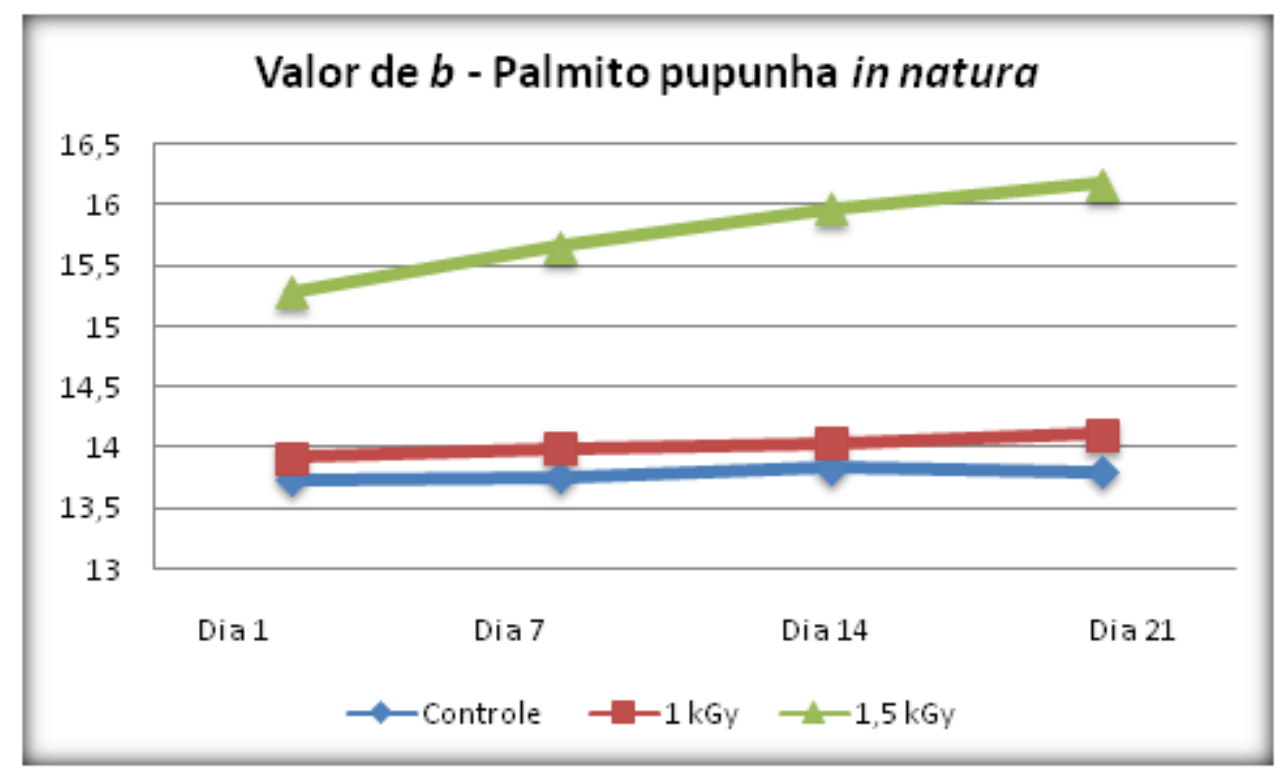

FIGURA 16. Fator $b$ para amostras de palmito pupunha in natura submetidas ao processo de radiação gama nas doses de 1 e 1,5 kGy armazenadas em diferentes períodos (valores médios).

Em estudo realizado por Barberi et al, 2008 com diferentes tipos de palmeiras obteve como resultados de cor nos parâmetros ( $L, a$ e $b)$ de palmitos em conserva indicaram leve escurecimento do produto durante os 12 meses de avaliação. Para o palmito Pupunha, os teores de verde ( $a$ negativo) e amarelo ( $b$ positivo) mais elevados indicaram coloração amarelada para esta espécie. Já o palmito da palmeira Real, em termos de coloração, assemelhou-se ao palmito da palmeira Açaí do gênero Euterpe, não alterando suas características em relação ao tempo inicial.

\subsection{Análises de cor em amostras de palmito minimamente processados irradiados no Multipropósito com fonte de ${ }^{60} \mathrm{Co}$.}

A tabela 5 mostra os valores médios de palmito pupunha minimamente processados e irradiado nas doses de 1 e 1,5 kGy e amostra controle. 
TABELA 5. Médias dos valores $L, a$ e $b$ de palmito pupunha minimamente processado e armazenados sob refrigeração de $8^{\circ} \mathrm{C}$.

\begin{tabular}{lcccc}
\hline & Dia 01 & Dia 07 & Dia 14 & Dia 21 \\
Valor de $\boldsymbol{L}$ & & & & \\
Controle & 81,29 & 81,36 & 81,41 & 81,44 \\
$1 \mathrm{kGy}$ & 82,59 & 82,52 & 82,61 & 82,55 \\
$1,5 \mathrm{kGy}$ & 82,19 & 81,28 & 81,03 & 81,61 \\
& & & & \\
Valor de $\boldsymbol{a}$ & & & & \\
& $-1,12$ & $-1,08$ & $-1,21$ & $-1,34$ \\
Controle & $-1,37$ & $-1,33$ & $-1,35$ & $-1,42$ \\
$1 \mathrm{kGy}$ & $-1,19$ & $-1,32$ & $-1,54$ & $-1,51$ \\
$1,5 \mathrm{kGy}$ & & & & \\
& & & & \\
Valor de $\boldsymbol{b}$ & & & & \\
Controle & 13,51 & 13,43 & 13,22 & 13,12 \\
$1 \mathrm{kGy}$ & 13,99 & 13,89 & 13,92 & 13,88 \\
$1,5 \mathrm{kGy}$ & 16,84 & 16,27 & 16,11 & 15,76 \\
\hline
\end{tabular}

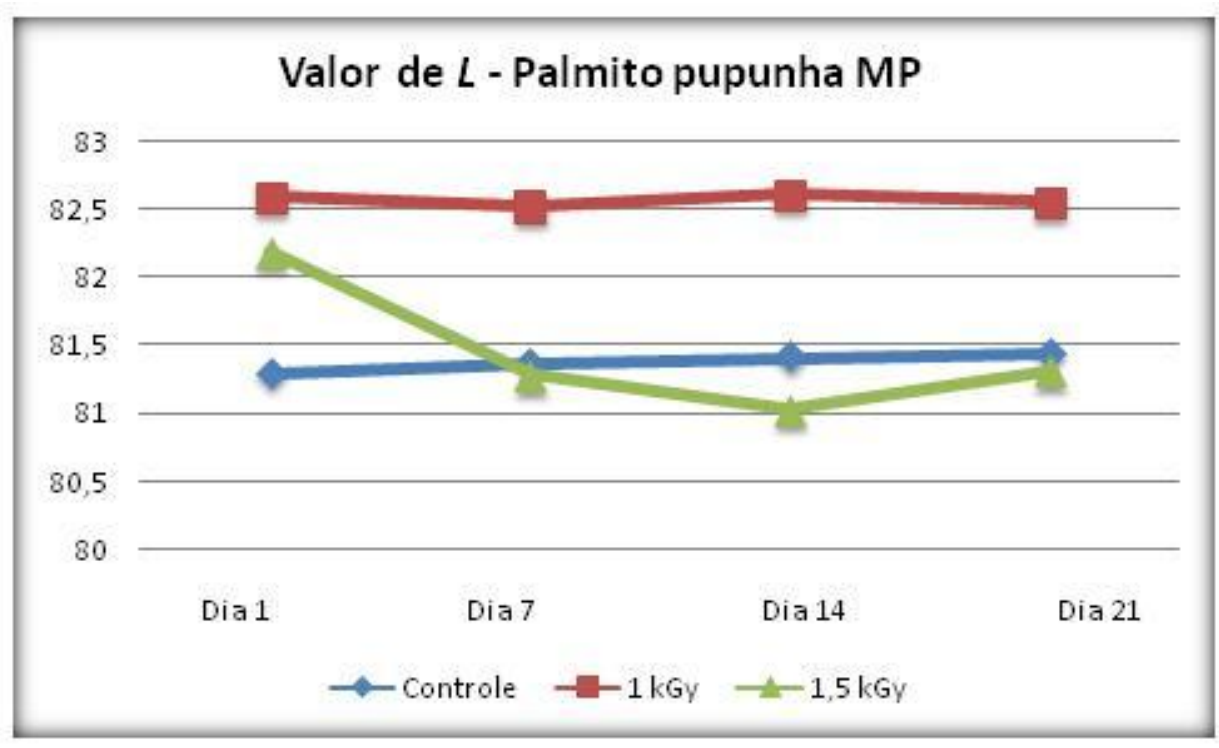

FIGURA 17. Fator $L$ (Luminosidade) para amostras de palmito pupunha minimamente processados, submetidas ao processo de radiação gama nas doses de 1 e 1,5 kGy armazenadas sob refrigeração em diferentes períodos (valores médios). 
Observamos na figura 17 os valores médios do parâmetro $L$, as amostras não sofreram escurecimento ao longo do período de armazenamento.

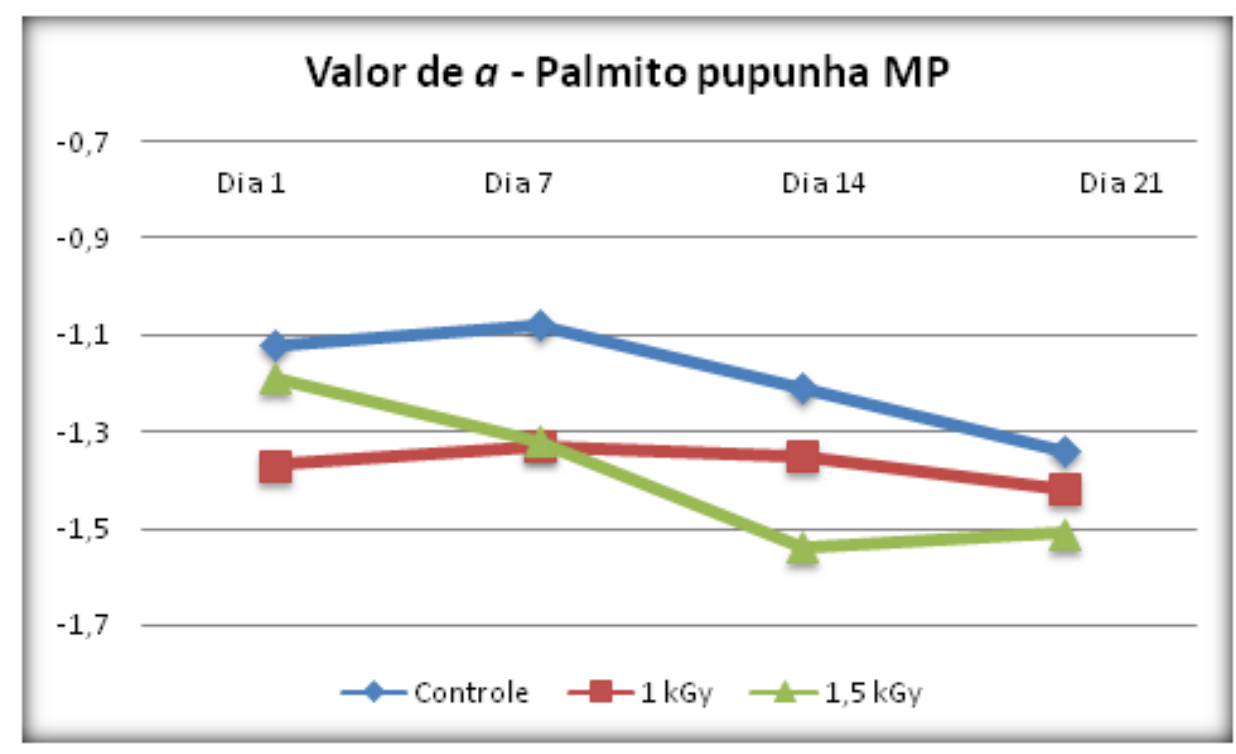

FIGURA 18. Fator $a$ (+a: vermelho, -a: verde) para amostras de palmito pupunha minimamente processados, submetidas ao processo de radiação gama nas doses de $1 \mathrm{e}$ 1,5 kGy armazenadas sob refrigeração em diferentes períodos (valores médios).

$\mathrm{Na}$ análise de cor para o parâmetro $a$ podemos observar na figura 18 que as amostras de palmito se comportaram da mesma forma, mesmo após o período de armazenamento, com exceção da amostra de 1,5 kGy, que demonstrou um decréscimo significativo ao longo do armazenamento apresentando uma tonalidade menos verde no período inicial e no final do período mostrou-se com um tom de verde mais acentuado, alterando significamente suas características naturais.

No parâmetro $b$ podemos observar que as amostras se diferenciaram entre si, principalmente as amostras irradiadas, mostrando com uma cor mais amarela (amanteigada) do que a amostra controle (Figura 19). 


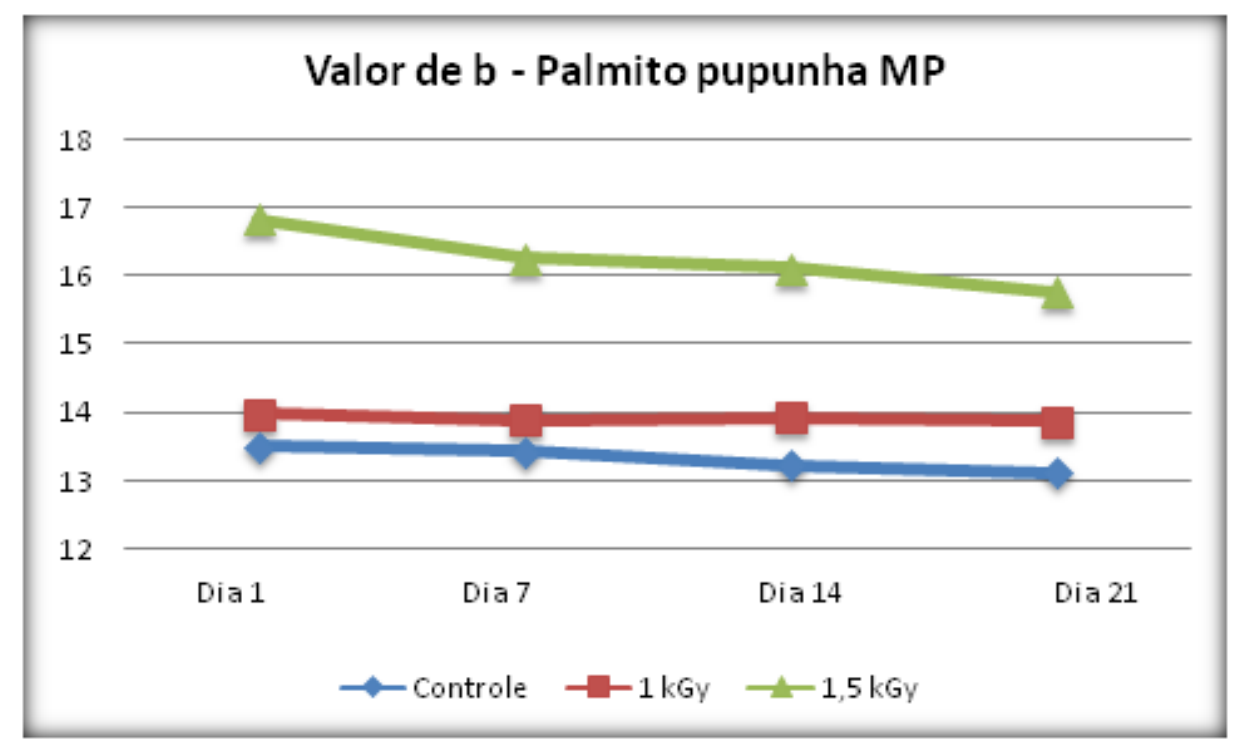

FIGURA 19. Fator $b$ de amostras de palmito pupunha minimamente processados, submetidas ao processo de radiação gama nas doses de 1 e 1,5 kGy e armazenadas sob refrigeração em diferentes períodos (valores médios).

Esses parâmetros são de extrema importância no ponto de vista para o consumidor, uma vez que estão acostumados com o palmito branco (que seria de outras espécies e não a deste estudo que tem uma coloração "amanteigada"), a amostra irradiada com a dose 1,5 kGy estaria muito diferente da amostra referência (controle) o que poderia levar a rejeição do produto.

Ferreira et al. (1982) avaliaram o palmito de pupunha em comparação com o palmito de Juçara, considerado de melhor qualidade e maior valor comercial. Ao contrário do palmito de Juçara, o palmito de Pupunha não apresentou atividade enzimática, tendo apresentado, após o processamento, cor amarelada e boa aceitação.

Verruma-Bernardi et al. (2003) estudando a aceitabilidade do palmito de pupunha picados e em rodelas, mostraram que apesar do palmito de pupunha não ter a cor e o sabor convencionais para o palmito a que se está acostumado, ele foi relativamente bem aceito.

O escurecimento observado em hortaliças geralmente é provocado pela ação de enzimas polifenoxidase, catalase e peroxidase sobre substratos presentes na folha do vegetal e pela ação da fenilalanina amônia liase, reguladora do metabolismo fenólico e 
resposnsável pela síntese de substratos para pelifenoloxidase e peroxidase, independente da ação da radiação (BROCHLEHURST, 1994).

Hanotel et al. (1995) observaram que a chicória picada irradiada com 3 kGy apresentou um escurecimento mais pronunciado que a amostra não irradiada porque a radiação provocou um aumento na permeabilidade das membranas lipídicas celulares e subcelulares o que teria facilitado o acesso das enzimas ao substrato.

O maior escurecimento de vegetais irradiados em relação a seus controles foram observados em alface americana picada (GOULARTE et al., 2004), em alface crespa roxa (ALLENDE et al. 2004) e em endívias (NIEMIRA et al., 2008).

\subsection{Análises de cor de palmito processado por Acelerador de Elétrons}

A tabela 6 mostra as médias dos parâmetros $L, a$ e $b$ de amostras da parte basal do palmito pupunha minimamente processados irradiados por acelerador de elétrons nas doses de 1 e 1,5 kGy.

TABELA 6. Médias dos valores $L, a$ e $b$ de palmito pupunha minimamente processado e armazenados sob refrigeração de $8^{\circ} \mathrm{C}$, submetidos à radiação ionizante em acelerador de elétrons.

\begin{tabular}{ccccc}
\hline Valor de $\boldsymbol{L}$ & Dia 01 & Dia 07 & Dia 14 & Dia 21 \\
Controle & 77,85 & 77,76 & 77,82 & 77,63 \\
$1 \mathrm{kGy}$ & 77,32 & 77,49 & 77,53 & 77,48 \\
$1,5 \mathrm{kGy}$ & 77,45 & 77,32 & 77,38 & 77,42 \\
& & & & \\
Valor de $\boldsymbol{a}$ & & & & \\
& & & & \\
Controle & $-0,78$ & $-0,77$ & $-0,81$ & $-0,86$ \\
$1 \mathrm{kGy}$ & $-0,76$ & $-0,79$ & $-0,78$ & $-0,84$ \\
$1,5 \mathrm{kGy}$ & $-0,78$ & $-0,78$ & $-0,82$ & $-0,89$ \\
& & & & \\
Valor de $\boldsymbol{b}$ & & & & \\
& & & & \\
Controle & 13,87 & 13,84 & 13,53 & 13,84 \\
$1 \mathrm{kGy}$ & 14,68 & 13,84 & 14,21 & 13,59 \\
$1,5 \mathrm{kGy}$ & 15,06 & 15,17 & 15,38 & 15,26 \\
\hline
\end{tabular}


No presente trabalho observamos na figura 20 que não ocorreu mudanças significativas no parametro $L$ entre as amostras irradiadas e não irradiada, não ocorrendo escurecimento ao longo do período de armazenamento.

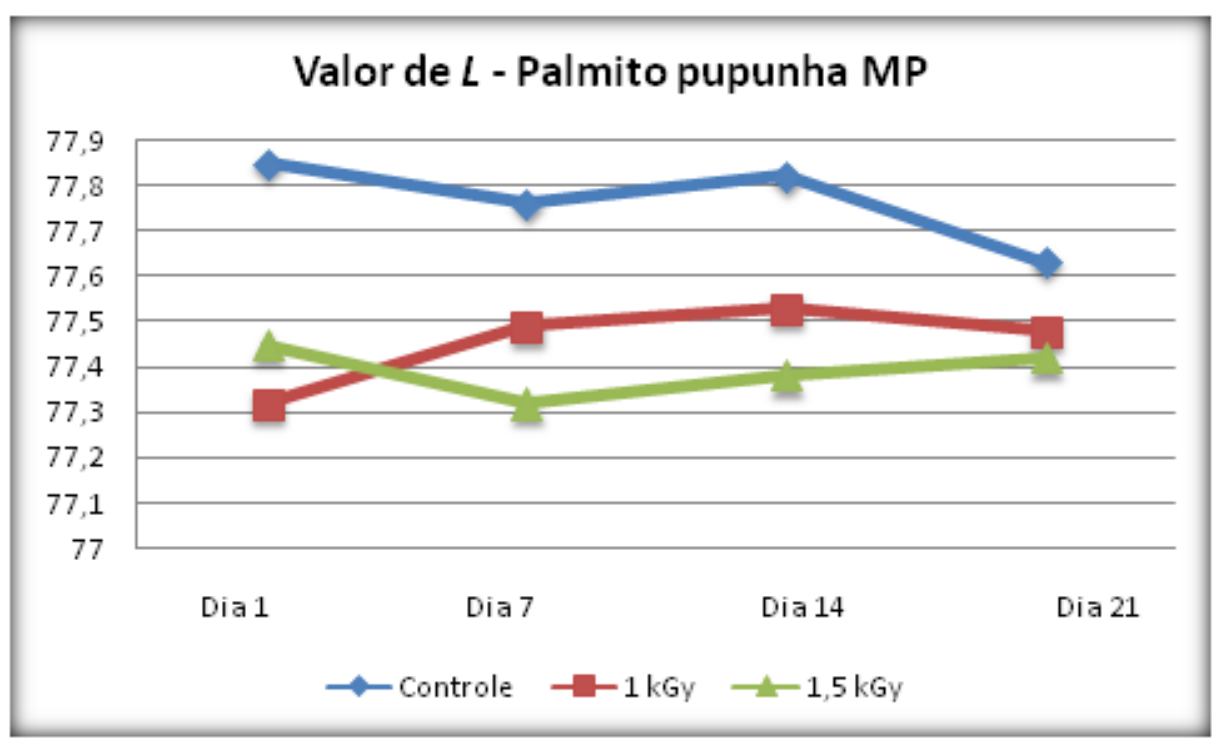

FIGURA 2. Fator $L$ (Luminosidade) para amostras de palmito pupunha MP, submetidas ao processo de radiação ionizante por acelerador de elétrons, irradiados nas doses de $1 \mathrm{e}$ 1,5 kGy, armazenadas sob refrigeração em diferentes períodos (valores médios).

As amostras não irradiadas e irradiadas não tiveram mudanças significativas, no entanto as amostras demonstraram um tom verde após 14 dias de armazenamento (figura 21).

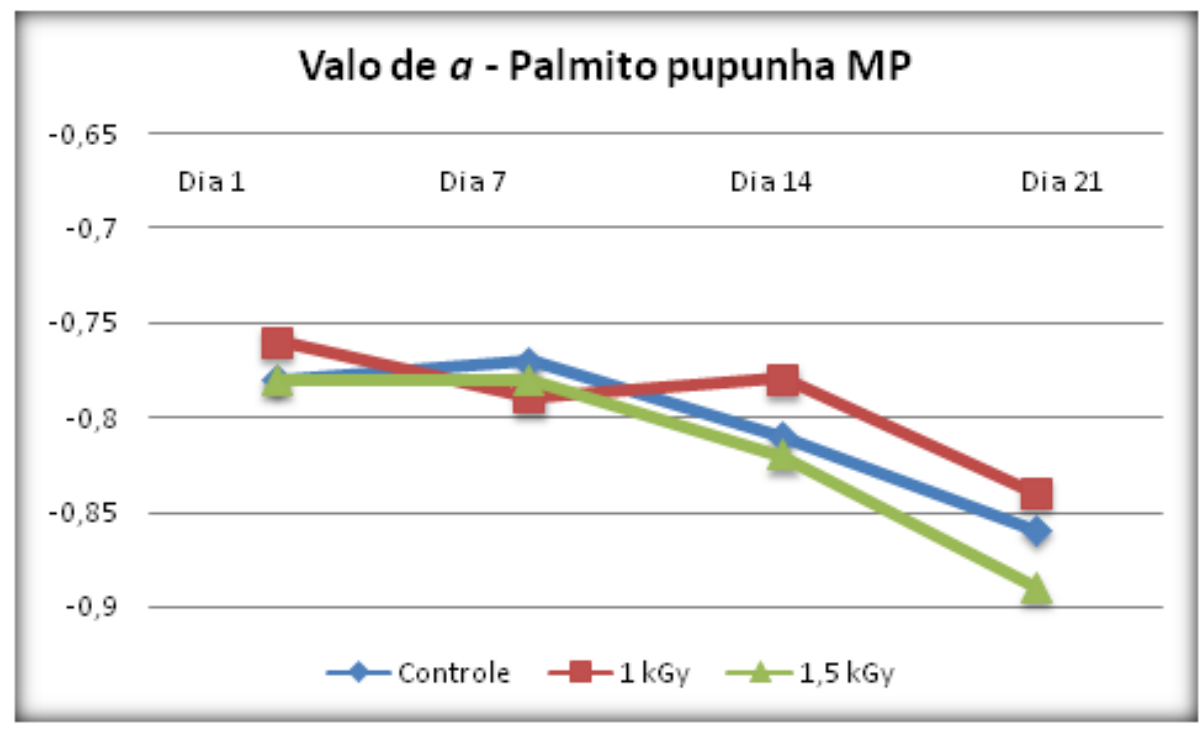

FIGURA 21. Fator $a$ de amostras de palmito pupunha MP, submetidas ao processo de radiação ionizante por acelerador de elétrons irradiados nas doses de 1 e 1,5 kGy e 
armazenadas sob refrigeração em diferentes períodos (valores médios).

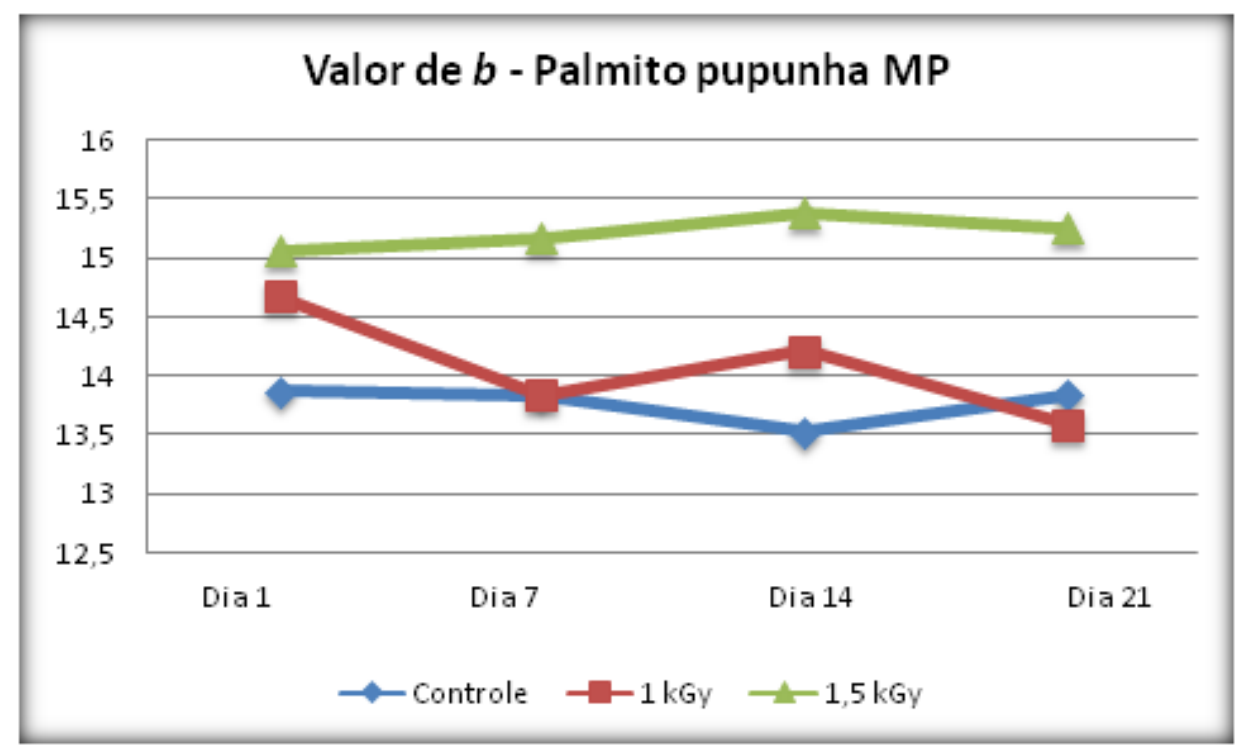

FIGURA 22. Fator $b$ de amostras de palmito pupunha MP, submetidas ao processo de radiação ionizante por acelerador de elétrons irradiados nas doses de 1 e 1,5 kGy e armazenadas sob refrigeração em diferentes períodos (valores médios).

O parâmetro $b$ apresentou variações entre as amostras, principalmente nas amostras irradiadas. A amostra irradiada na dose de $1 \mathrm{kGy}$ sofreu mais alterações ao longo do período armazenado (figura 22).

Jin et al. (2007) avaliou o efeito da radiação ionizante por feixes de elétrons nas características de cor em amostras de Ginseng, no qual concluiu que o tratamento não causou alterações significativas nas amostras irradiadas com doses de 2, 8 e 16 kGy.

\section{Análise de textura em palmito pupunha in natura irradiados em multipropósito.}

A textura pode ser definida como a manifestação sensorial e funcional das propriedades estruturais, mecânicas, e de superfície de alimentos, detectada através dos sentidos da visão, audição e tato. Os instrumentos de análise de textura podem detectar e quantificar somente alguns parâmetros físicos, que devem ser interpretados em termos de percepção sensorial. Como método instrumental, a análise de textura envolve a compressão da substância a ser testada e a quantificação dos parâmetros mecânicos através da curva força/deformação. Alguns dos parâmetros de textura, como dureza, firmeza e maciez estão na escala de resistência do alimento à aplicação de forças 
compressivas. Sensorialmente, a firmeza de um alimento é entendida como a força requerida para comprimir uma substância entre os dentes molares (SZCZENIAK, 2002). A firmeza é a propriedade de textura que atrai maior atenção à avaliação devido à sua próxima associação a percepção humana de frescor (CARR; TADINI, 2003).

Os resultados obtidos na análise de textura do palmito pupunha encontram-se na tabela 7. Através das observações dos dados obtidos, pode-se perceber que as amostras de palmito pupunha in natura diferiram estatisticamente ao nível de 5\% entre as amostras analisadas. As variações de todos os tratamentos e épocas de análises podem ser explicadas, em parte, pela heterogeneidade em diâmetro do produto, embora todas as palmeiras utilizadas no processamento procederam do mesmo local.

TABELA 7. Textura de palmito minimamente processados irradiados por radiação gama, armazenados por 21 dias.

\begin{tabular}{ccccc}
\hline \multicolumn{5}{c}{ Textura / Força (N) } \\
\hline Doses & Dia 1 & Dia 7 & Dia 14 & Dia 21 \\
& Controle $^{\text {a }}$ & $3,9^{\mathrm{a}}$ & $2,4^{\mathrm{a}}$ & $2,6^{\mathrm{ab}}$ \\
$\mathbf{1} \mathbf{~ k G y}$ & $4,3^{\mathrm{a}}$ & $3,5^{\mathrm{ab}}$ & $2,6^{\mathrm{a}}$ & $2,1^{\mathrm{a}}$ \\
$\mathbf{1 , 5} \mathbf{k G y}$ & $4,4^{\mathrm{a}}$ & $3,7^{\mathrm{a}}$ & $3,3^{\mathrm{ab}}$ & $2,2^{\mathrm{a}}$ \\
\hline
\end{tabular}

Letras maiúsculas distintas diferem ao nível de 5\% de probabilidade entre os tratamentos.

Em estudo, Verruma-Bernardia et al. (2007) analisou palmito pupunha sobre as características de maciez, e mostrou em seus resultados que as amostras de palmito de diferentes marcas se diferiram significativamente entre si $(\mathrm{p}<0,05)$, possuindo uma amostra de palmito com a textura menos firme (macia) e as outras amostras com a textura mais firme.

\subsection{Análise da textura de palmito pupunha minimamente processados irradiados no multipropósito.}


Na tabela 8 podemos observar os resultados da textura de amostras de palmito minimamente processados. Os resultados demonstram que ao longo do período de armazenamento as amostras mostram perda da firmeza do produto.

TABELA 8. Textura de palmito in natura processados por radiação gama, armazenados por 21 dias.

\begin{tabular}{ccccc}
\hline \multicolumn{5}{c}{ Textura / Força (N) } \\
\hline Doses & Dia 1 & Dia 7 & Dia 14 & Dia 21 \\
Controle & $5,3^{\mathrm{a}}$ & $3,2^{\mathrm{a}}$ & $2,5^{\mathrm{a}}$ & $2,1^{\mathrm{a}}$ \\
$\mathbf{1} \mathbf{~ k G y}$ & $5,3^{\mathrm{a}}$ & $3,8^{\mathrm{ab}}$ & $2,5^{\mathrm{a}}$ & $2,7^{\mathrm{ab}}$ \\
$\mathbf{1 , 5} \mathbf{~ k G y}$ & $5,2^{\mathrm{a}}$ & $3,7^{\mathrm{ab}}$ & $3,4^{\mathrm{ab}}$ & $3,5^{\mathrm{ab}}$ \\
\hline
\end{tabular}

Letras maiúsculas distintas diferem ao nível de 5\% de probabilidade entre os tratamentos.

No presente trabalho observamos que não há mudanças nas amostras iniciais, porém a partir do dia 7 e no final do período de armazenamento as amostras de 1 kGy sofreram alterações. As amostras de 1,5 kGy no dia 07 até o dia 21 apresentou mudanças significativas ao nível de $5 \%$ de probabilidade.

Campos et al. (1978) realizaram experimentos com conservas de toletes da palmeira juçara onde foram estudados os tempos de cozimento de 20, 35, 50 e 65 minutos nas épocas de zero, 15, 45 e 90 dias de estocagem após o processamento, relataram que não foi observada diferença significativa na textura dentro do período de armazenamento estudado.

De acordo com Varoquaux et al. (1990) fatias de kiwi MP armazenados a $2^{\circ} \mathrm{C}$ perderam $50 \%$ da firmeza inicial em um período menor que 2 dias. Os autores relatam que a perda da firmeza dos tecidos de fatias de kiwi MP ocorre possivelmente em decorrência da hidrólise de componentes da parede celular por enzimas pectinolíticas liberadas pelas células danificadas e que se difundem pelos tecidos mais internos.

A textura do vegetal está relacionada com a integridade da estrutura da pectina e da celulose. Quando essas estruturas são afetadas, a textura do vegetal fica comprometida. Howard et al. (1995) verificaram a alteração na solubilidade da pectina e 
redução no grau de esterificação da celulose em tomate, pimenta e cebola minimamente processados e irradiados com $1 \mathrm{kGy}$ e armazenado durante 1 semana. Estas alterações levaram a perda de textura desses vegetais. Alterações semelhantes foram observadas por Goularte et al. (2004) em alface americana picada e irradiada com 1,1 kGy após 24 horas; em aipo cortado exposto a $1 \mathrm{kGy}$, armazenado durante 15 dias (PRAKASH et al, 2000b) e em alface exposta a 0,35 kGy (PRAKASH et al. 2000a). Porém outros autores (FOLEY et al., 2002; NIEMIRA et al., 2001 e NIEMIRA et al., 2003) não observaram alterações na estrutura de alface e endívia expostas a doses de até $1 \mathrm{kGy}$, resultados semelhantes a este estudo, onde não foi possível alterações significativas na textura do palmito pupunha minimamente processados.

\subsection{Análise de textura de palmito pupunha minimamente processados irradiados em acelerador de elétrons.}

As doses de radiação absorvidas pelo palmito não influenciaram significativamente na firmeza. Na tabela 9 podemos observar que os valores estão próximos, mesmo após o período de armazenamento. Os desvios obtidos indicam que a textura dos palmitos analisados, para cada dose e a para a amostra controle não é uniforme, podendo variar de uma amostra para outra.

TABELA 9. Textura de palmito minimamente processados irradiados por feixes de elétrons armazenados por 21 dias.

\begin{tabular}{ccccc}
\hline \multicolumn{5}{c}{ Textura / Força (N) } \\
\hline Doses & Dia 1 & Dia 7 & Dia 14 & Dia 21 \\
& $4,2^{\mathrm{a}}$ & $4,2^{\mathrm{a}}$ & $4,4^{\mathrm{a}}$ & $4,5^{\mathrm{a}}$ \\
Controle & $4,3^{\mathrm{a}}$ & $4,4^{\mathrm{a}}$ & $4,5^{\mathrm{a}}$ & $4,4^{\mathrm{a}}$ \\
$\mathbf{1} \mathbf{~ k G y}$ & $4,2^{\mathrm{a}}$ & $4,3^{\mathrm{a}}$ & $4,4^{\mathrm{a}}$ & $4,3^{\mathrm{a}}$ \\
\hline
\end{tabular}

Letras maiúsculas distintas diferem ao nível de $5 \%$ de probabilidade entre os tratamentos.

Foi possível observar no presente trabalho que as amostras de palmito pupunha minimamente processado submetido ao processo de irradiação por feixes de elétrons, não demonstraram diferença na característica de textura, o que não compromete as características sensoriais do alimento estudado. 
Fatias de melão irradiadas por feixe de elétrons $(0 ; 0,7$ e $1,4 \mathrm{kGy})$ foram analisadas no $21^{\circ}$ dia de estocagem em relação aos parâmetros sensoriais. Verificou-se que não houve alteração da cor fruta. Houve alteração na textura no melão irradiado na dose de 1,4 kGy (PALEKAR et al., 2004).

\section{Análise Sensorial}

De acordo com Meilgaard et al, (1999), pode-se inferir a preferência dos consumidores em função dos valores relativos de aceitabilidade obtidos nos testes afetivos, ou seja, as amostras com maiores notas foram as mais preferidas pelos provadores.

A utilização da análise sensorial tem sido bastante aplicada e recomendada, uma vez que esta pode contribuir na descrição dos referidos produtos e estabelecer a vida útil dos mesmos (DELIZA, 2000).

Na tabela 10 observamos os resultados da análise sensorial realizada na indústria "Floresta Indústria e Comércio Ltda.". Os resultados mostram os parâmetros globais e aparência nas amostras de palmito pupunha irradiado nas doses de 1 e $1,5 \mathrm{kGy}$ e a amostra controle.

TABELA 10. Médias dos resultados da análise sensorial para os parâmetros global e de cor das partes nobre e basal de palmito.

\begin{tabular}{ccccc}
\hline Amostras & \multicolumn{2}{c}{ Global } & \multicolumn{2}{c}{ Aparência } \\
& Nobre & Basal & Nobre & Basal \\
\hline Controle & $3,5^{\mathrm{a}}$ & $2,9^{\mathrm{a}}$ & $3,8^{\mathrm{a}}$ & $3,6^{\mathrm{a}}$ \\
$\mathbf{1} \mathbf{~ k G y}$ & $4,1^{\mathrm{a}}$ & $2,0^{\mathrm{a}}$ & $3,1^{\mathrm{a}}$ & $4,0^{\mathrm{a}}$ \\
$\mathbf{1 , 5} \mathbf{~ k G y}$ & $4,3^{\mathrm{a}}$ & $4,4^{\mathrm{b}}$ & $5,4^{\mathrm{b}}$ & $4,6^{\mathrm{a}}$ \\
\hline
\end{tabular}

$\overline{\text { Letras maiúsculas distintas diferem ao nível de 5\% de probabilidade entre os tratamentos. }}$

O parâmetro global nas amostras da parte nobre de palmito pupunha não apresentou diferença significativa ao nível de 5\% de significância, já a amostra de 1,5 
kGy da parte basal apresentou diferença significativa, sendo assim, a dose menos preferida pelos provadores.

No parâmetro de cor da parte nobre do palmito ocorreu uma diferença significativa ao nível de $5 \%$ de probabilidade na dose de $1,5 \mathrm{kGy}$, o que não ocorreu com as amostras de palmito da parte basal não havendo diferença entre as amostras.

Podemos ressaltar que as amostras de 1,5 kGy obtive notas negativas de acordo com os resultados da análise sensorial.

A aparência do produto exerce papel fundamental na decisão de compra do consumidor, uma vez que é através da observação deste parâmetro que o consumidor seleciona, escolhe e consome o alimento. Assim, a disponibilidade no mercado de produtos com qualidade sensorial adequada, contribui para a satisfação do consumidor, favorecendo um maior consumo do produto em questão (DELIZA, 2000).

Segundo Ferreira et al. (1982) e Verruma-Bernardi, et al. (2003), o palmito de pupunha tem apresentado boa aceitação no mercado, sendo capaz de competir com palmitos das palmeiras do gênero Euterpe.

Em estudo com folhas de alface refrigeradas $\left(1\right.$ e $\left.4^{\circ} \mathrm{C}\right)$ submetidas à irradiação em doses de 0,33 e 0,53 kGy e estocadas por um período acima de 10 dias, verificou-se que não houve alteração sensorial no amolecimento do alface irradiado. Concluiu-se que a aparência e sabor foram mais alterados por causa do tempo de estocagem do que por condições de temperatura (FOLEY et al., 2002).

Para folhas de coentro irradiadas na dose de até $2 \mathrm{kGy}$, não houve alteração na qualidade nutricional e sensorial de cor, textura e aroma (FAN et al., 2003; SOMMERS et al., 2004).

Arevalo et al. (2002) estudaram por análise sensorial mudanças induzidas por radiação de ${ }^{60} \mathrm{Co}$ com dose de 0,15;0,25 e 0,35 kGy em abacate in natura. Os provadores julgaram tão aceitáveis as frutas irradiadas quanto aquelas não irradiadas. 


\section{CONCLUSÕES}

As análises microbiológicas de palmito pupunha mostraram que a radiação ionizante promove diminuição da carga microbiana em ambos os tratamentos, contribuindo para aumentar a segurança microbiológica deste alimento.

Nas análises de cor podemos concluir que em todos os tratamentos a dose de 1,5 kGy apresentou mais diferença em relação as outras amostras analisadas.

Nas características de textura do palmito, observamos que a radiação gama modificou a textura do palmito, ao contrário do tratamento por feixes de elétrons que não demonstrou diferenças entre as amostras analisadas.

Nas condições do presente trabalho podemos concluir que a dose de $1 \mathrm{kGy}$ processado por radiação gama mostrou ser a mais apropriada para a irradiação do produto estudado, pois não ocorreu alterações significativas nas características sensoriais do palmito pupunha.

Podemos ressaltar que o palmito pupunha in natura irradiado com ${ }^{60} \mathrm{Co}$ teve uma vida útil de aproximadamente 21 dias, o que beneficia a prática da venda in natura e conseqüentemente reduz os custos na comercialização. 


\section{REFERÊNCIAS}

ABNT - NBR 12806 - Análise Sensorial de Alimentos e Bebidas. Fevereiro, 8 páginas, 1993.

ALLENDE, A.; AGUAYO, E. ARTÉS, F. Microbial and Sensory quality of commercial fresh processed red lettuce throughoout the protection chain and shelf life. Int. Jounal Food Microbiological., v. 91, p. 109-117, 2004.

ALMEIDA, S. P.; PROENÇA, C. E. B,; SANO, S. M.; RIBEIRO, J. F. Cerrado: espécies vegetais úteis. Planaltina, DF: EMPREPA, CPAC, 1998, 446 p.

ALMEYDA, N.; MARTIN, F.W. The pejibaye. In: Cultivation of neglected tropical fruits with promise. Department of Agricultural of United States; Washington, 1980. 8p.

ARAÚJO, M.M.; Duarte, R.C.; Silva, P.V; Marchioni E. and Villavicencio, A.L.C.H. Application of the microbiological method DEFT/APC to detect minimally processed vegetables treated with gamma radiation, Radiation Physics and Chemistry(2009).

AQUINO, S. Efeitos da radiação gama no crescimento de Aspergillus flavus produtor de aflatoxinas e no emprego da técnica da reação em cadeia de polimerase (PCR) em amostras de grãos de milho inoculadas artificialmente. 2003. Dissertação (Mestrado) Instituto de Pesquisas Energéticas e Nucleares, São Paulo.

BRASIL a . Ministério da Saúde. Decreto-Lei no 986, de 21 de outubro de 1969. Institui Normas Básicas sobre Alimentos. Publicada no DOU de 21 de outubro de 1969. Alterado pela Medida Provisória no 2.190-34, de 23 de agosto de 2001.

BRASIL ${ }^{\mathrm{b}}$. ANVISA. Resolução RDC $\mathrm{n}^{\mathrm{o}}$ 12, de 02 de Janeiro de 2001. Aprova o regulamento técnico sobre padrões microbiológicos para alimentos. Publicada no DOU de 10 de janeiro de 2001.

BELLEGARD, C.R.G; RAUPP, D.S.; CHAIMSOHN, F.P.; BORSATO, A.V. Avaliação de procedimentos de acidificação de conservas de palmito foliar de Pupunha (Bactris gasipaes). Acta Scientiarum Agronomy, Maringá, v.27, n.2, p.247-254, 2005.

BERBARI, H.A.G.; PRATI, P.; JUNQUEIRA, V.C.A. Qualidade do palmito da palmeira real em conserva. Ciência e Tecnologia de Alimentos, Campinas, 28 (Supl.): 135-141, 2008.

BERNHARDT, L.W. Características do palmito da pupunheira do ponto de vista do processamento. In: SEMINÁRIO DO AGRONEGÓCIO, 1. Palmito de pupunha na 
Amazônia, 1999. Porto Velho. Anais... Porto Velho: EMBRAPA-CPAF, Rondônia, 1999, 93p. Documentos 41, p.24-33.

BEUCHATM L.R.; COPELAND, F.; CURIALE, M.S. et al. Comparison of the SimPlate Total Plate Cont method with Petrifilm, Redigel, and conventional pour-plate methods for enumerating aerobic microorganisms in foods. Journal of Food Protection, v.6, n.1, p.14-18, 1998.

BOLIN, H.R.; HUXSOLL, C.C. Storage stability of minimally processed fruit. Journal of Food Processing and Preservation, v.13, p.281-292, 1989.

BOHORQUEZ N. R.; YEAZA, C. H. Estudio experimental del aprovechamiento del fruto del Pejibaye (Guilielma Gasipaes) / Experimental study of utilization the pejibaye fruit (Guilielma Gasipaes). Revista de la Universidad de Guayaquil; 72(2):103-13, 1988.

BONACCINI, L.A. Produza palmito: a cultura da pupunha. Cuiabá: SEBRAE/MT, 1997. 100p. (Coleção Agroindústria, 12).

BOVI, M.L.A. O agronegócio palmito de pupunha. Horticultura Brasileira, Brasília, v.21, n.1, capa, 2003.

CHAIMSOHN, F.P. Cultivo de pupunha e produção do palmito. Viçosa: Aprenda Fácil. 2000. 121p.

CAMACHO, V.E.; SORIA, J.V. Pejibaye palmcore. Proceedings of the American Society for Horticultural Science, Geneva, v.14, p.122-132, 1970.

CHAIMSOHN, F.P. Cultivo de pupunha para palmito. Importância, mercado e aspectos biológicos e agronômicos. In: CHAIMSOHN, F.P. (Coord.) Curso sobre cultivo e processamento de palmito de pupunha e introdução ao cultivo de palmeira real para palmito, Londrina, Instituto Agronômico do Paraná (IAPAR), 2001. p.4-149.

CLEMENT, C.R.; SANTOS, L.A.; ANDRADE, J.S. Conservação de palmito de pupunha em atmosfera modificada. ACTA Amazônica, Manaus, v.29, n.3, p.437-445, 1999.

CLEMENT, C.R. Pupunha, uma árvore domesticada. Ciência Hoje, Rio de Janeiro, v.5, p.66-73, 1987.

CLEMENT, C.R.; SANTOS, L.A.; ANDRADE, J.S. Conservação de palmito de pupunha em atmosfera modificada. ACTA Amazônica, Manaus, v.29, n.3, p.437-445, 1999. 
CLEMENT, C.R.; BOVI, M.L.A. Padronização de medidas de crescimento e produção em experimentos com pupunheira para palmito. ACTA Amazônica, Manaus, v.30, n.3, p.349-362, 2000.

DELLA MODESTA, R.G. Manual de análise sensorial de alimentos e bebidas. Rio de Janeiro: EMBRAPA/CTAA.,1994. v.1, 52p.

DIEHL, J.F. Food Irradiation: is it an alternative to chemical preservatives? Food Addit. Contam., v. 9, p. 409-416, 1992.

DIEHL, J.F. Safety of Irradiated Foods. New York: Marcel Dekker Inc., 1995.

DIEHL, J.F. Food Irradiation - past, present and future. Rad. Phys. Chem., v. 63, p. 211-215, 2002.

DIEHL, J.F.Food Irradiation - Past, Present, and Future Radiation Physics and Chemistry 63, 211-215, 2002.

DIEHL, J. F. Safety of irradiated foods, Marcel Deckker, New York (1995).

DELINCÉE, H. Detection of food treated with ionizing radiation. Trends Food Sci. Technol., v. 9, n.2, p. 73 - 82, 1998.

DELINCÉE, H.; VILLAVICENCIO, A. L. C. H.; MANCINI-FILHO, J. Protein quality of irradiated Brazilian beans. Rad. Phys. Chem., v. 52, n. 1-6, p. 43-48, 1998.

DELINCÉE, H. Analytical methods to identify irradiated food -a review. Rad. Phys. Chem., v. 63, p. 455-458, 2002.

DELIZA, R. Importância da Qualidade sensorial em produtos minimamente processados. II Encontro nacional sobre processamento mínimo de frutas e hortaliças, Universidade Federal de Viçosa, Viçosa-MG, p. 73-74, 2000.

DUTCOSKY, S.D. Análise sensorial de alimentos. Curitiba: Editora Champagnat, 1996. $123 \mathrm{p}$.

EMBRARAD. 2003, http://www.embrarad.com.br/alimentos.

FAN, X. and SOKORAI, K.J.B. Changes in volatile compounds of $\gamma$-irradiated fresh cilantro leaves during cold storage. Journal of Agricultural and Food Chemistry 50:7622-7626. 2002. 
FARKAS, J. Irradiation for better Foods. Trends Food Sci.. Technol., v. 17, p. 148152, 2006.

FARKAS, J. Physical Methods of Food Preservation - Preservatives and Preservation Methods. In: DOYLE, M.P, BEUCHAT, L.R, MONTVILLE, T.J., Food Microbiol.: fundamentals and frontiers. 2 ed. Washington: ASM, 2001, p. 567-591.

FARIA, J. B.; FERREIRA, V.; LOPEZ, R.; CACHO, J. The sensory characteristic defect of cachaça distilled in absence of copper. Alimentos e Nutrição.14: 1-7, 2003.

FRANCO, B. D. G. M.; LANDGRAF, M. Microbiologia dos Alimentos. São Paulo: Atheneu, 1996, 182p.

FAO/ INTERNATIONAL ORGANIZATION OF ENERGY ATOMIC/ ORGANIZATION MUNDIAL DE LA SAULUD. Bases tecnicas para la legislacion referente a los alimentos irradiados. Roma, 1966. 62p.

FDA - FOOD AND DRUG ADMINISTRATION. Irradiation of meat and meat products. Federal Register, v. 64, n. 36, p. 9089-9105, 1999.

FERREIRA, S.A.N. Pupunha, Bactris gasipaes Kunth. In: FERRAZ, I.D.K.; CAMARGO, J.L.C. Manual de sementes da Amazônia. Manaus: INPA, 2005. v.5. 12p.

FERREIRA, S.R.S. Contribuição da tecnologia de irradiação de alimentos no fornecimento de segurança alimentar e nutricional. 1999. 172f. Dissertação (Mestrado em Nutrição Humana) - Instituto de Nutrição, Universidade Federal do Rio de Janeiro, Rio de Janeiro.

FERREIRA, V. L. P.; GRANER, M.; BOVI, M. L. A.; DRAETTA, I. S.; PASCHOALINO, J. E.; SHIROSE, I.Comparação entre os palmitos de Guilielma gasipaes Bailey (pupunha) e Euterpe edulis Mart. (juçara): II.avaliações físicas e químicas. Coletânea do Instituto de Tecnologia de Alimentos (ITAL), Campinas, v. 12, n. 1, p. 273-282, 1982.

FENNEMA, O.R.; DAMODARAN, S.; PARKIN, K. Fennema's Food chemistry, 4.ed. Boca Raton: CRC Press, 2007. 1100p.

FOLEY, D.M. REHER, E.; CAPORASO, F.; TRIMBOLI, S.; MUSHERRAF, Z.; PRAKASH, A. Elimination of. L. monocytogenes and changes in physical and sensory qualities of prepared meal following gamma irradiation. Food Microbiol., v.18, p. 193204, 2001.

FUMENTO, M. Irradiation: a winning recipe for wholesome beef. Priorities, v. 6, n. 2, p. 37-39, 1994. 
GAO. Food Irradiation: Available Research Indicates that Benefits Outweigh Risks. GAO/RCED-00-217. U.S. General Accounting Office, Washington, D.C., 2000.

HANOTEL, L., Fleuriet, A., Boisseau, P., 1995. Biochemical changes involved in browning of gamma-irradiated cut witloof chicory. Postharvest Biol. Technol. 5, 199210.

HENDERSON, P.A. Mark-recapture methods for population size estimation, pp. 48-59. In Practical Methods in Ecology, Blackwell Publishing, Oxford, UK, 2003.

HOJEIJE, Y. K. APPCC no plantio e na industrialização do palmito. Necessidade ou obrigação? Revista Higiene Alimentar. v.20, n.139, mar. 2006.

HOWARD, L. R.; MILLER, G.H.; WAGNER, A.B. Microbiological chemical, and sensory changes in irradiated pico de gallo. Journal Food Science., v.60, n.3, p. 461464, 1995.

HUNTERLAB. Applications Note, v. 8, n. 7, 1996. Disponível em: <http://www.hunterlab.com> Acesso em: 14 de ago. de 2008.

IAL - Instituto Adolfo Lutz. Métodos físico-químicos para análises de alimentos. 4. ed. São Paulo: Instituto Aldolfo Lutz, 2005. 1018p.

ICGFI - GRUPO CONSULTIVO INTERNACIONAL SOBRE IRRADIAÇÃO DE ALIMENTOS (ICGFI). Fatos sobre a irradiação de alimentos. Brasil: CDTN, 1999.

INTERNATIONAL ATOMIC ENERGY AGENCY (IAEA). Information from the International Atomic Energy Agency, www.iaea.org/nafa/d5/public/foodirradiation.pdf, Data de acesso: 14 de Maio de 2009.

JAY, J. M. Modern Food Microbiology. New York: International Thomson Publishing, 2001.

JAY, J.M. Modern food microbiology. 5.ed. Gaithersburg: Aspen Publishers, 1998. $661 \mathrm{p}$.

JIMENEZ, E. Evaluación de alternativas tecnológicas para la conservación del palmito de pejibaye como producto fresco. Corbana, v. 16, n. 38, p. 34-40, 1992.

JIN, Y.; SHIN, H. AND SONG, K. B. Electron Beam Irradiation Improves Shelf Lives of Korean Ginseng (Panax ginseng C.A. Meyer) and Red Ginseng. JOURNAL OF FOOD SCIENCE, Vol. 72, Nr. 4, 2007.

KASMIRE, R. F.; CANTWELL, M. Postharvest Handling Systems: Fruit Vegetables. In: Kader, A. A. Postharvest Technology Of Horticultural Crops. 2.ed. Oakland: 
University of California, Division of Agriculture and Natural Resources. Publication 3311,1992 , p.45-53.

KAPP, E. A. et al. Tempo de preservação de tolete de palmito pupunha (Bactris gasipaes) minimamente processado e armazenado sob refrigeração. Publicatio, Ponta Grossa, v. 9, n. 3, p. 51-57, 2003.

LIMA, K. S. C., Grossi, J. L.; LIMA, A.L.S.;ALVES, P. E. M. P.; CONEGLIAN, R. C. C.; GODOY, R. L. O. e SABAA-SRUR, A.V.O. Efeito da radiação ionizante (y) na qualidade pós-colheita de cenouras (Daucus carota I.) cv. Nantes. Campinas: Ciencia e tecnologia de Alimentos, v.2, M: n.2,p., 2001.

LEE, N. Y.; JO, C.; SHIN, D. H.; KIM, W. G.; BYUN, M. W. Effect of $\gamma$-irradiation on pathogens inoculated into ready-to-use vegetables. Food Microbiol., v. 23, p. 649-656, 2006.

LOAHARANU, P. Food irradiation in developing countries a practical alternative. 1994, p.30-35. (International Atomic Energy Agency Bulletins 1).

MALISKA, C. Conservação de alimentos por irradiação. Revista Higiene Alimentar, v. 11, n. 68/69, p. 16-17, 2000.

MACHADO, E. J. Dificuldades da comercialização de hortaliças minimamente processadas. Horticultura Brasileira, v.19, Suplemento, Palestras, jul.2001.

MARCHIONI, E., HORVATOVICH, P., CHARON, H., KUNTZ, F., 2005, 'Detection of irradiated ingredients included in low quantity in non-irradiated food matrix. 2. ESR Analysis of mechanically recovered poultry meat and TL Analysis of Species", J. Agric. Food Chem. V.53, pp.3774-3778.

MATIN, M. A.; BHUIYA, A. D.; AMIN, M. R.; MALEK, M. A. Irradiation of onions, pulses and dried fish: process control, storage, test marketing and economic analysis of the process. Vienna: IAEA, 1996. p. 19-49. (TECDOC, 871).

MARTINS, C.G.; BEHRENS, J.H.; DESTRO, M.T.; FRANCO, B.D.G.M. ; VIZEU, D.M. ; HUTZLER, B. W.; LANDGRAF, M. Gamma radiation in the reduction of Salmonella spp. inoculated on minimally processed watercress (Nasturtium officinallis). Rad. Phys. Chem., v. 71,-/ p. 87 - 91, 2004.

MARTINS, C.G, FRODER, H.; SOUZA, K.L.O; FRANCO, B.D.G.M.; LANDGRAF, M.; DESTRO, M.T. Ecologia microbiana de vegetais folhosos minimamente processados. In: XXII Congresso Brasileiro de Microbiologia 2003, 17-20 de Novembro de 2003, Florianópolis / Santa Catarina, p. 154, 2003. 
MEILGAARD, M.; CIVILLE, G.V.; CARR, B.T. Sensory evaluation techniques. $3^{\circ}$ ed. Washington, D.C, 1999.

MINTIER, A.M. and FOLEY, D.M. Electron beam and gamma irradiation effectively reduce Listeria monocytogenes populations on chopped romaine lettuce. Journal of Food Protection 69:570-574. 2006.

MOLLINS, R.A.; MOTARJEMI, Y.; KÄFERSTEIN, F.K. Irradiation: a critical control point ensuring the microbiological safety of raw foods. Food Control, v.12, n.6, p.347-356, 2001.

MONK, J.D.; BEUCHAT, L.R.; DOYLE, M.P. Irradiation inactivation of food-borne microrganisms. J. Food Prot., v. 58, n. 2, p.197-208, 1995.

MORALES, A. A. La evaluación sensorial de los alimentos em la teoría y la práctica. Zaragoza: Acribia, 1994.

MORA-URPI, J.; WEBER, J.C.; CLEMENT, C.R.; Peach palm, Bactris gasipaes Kunth. Promoting the conservation and use of underutilized and neglected crops. Roma: Institute of Plant Genetics and Crop Plant Research, 1997. 83p. (International Plant Genetic Resources Institute, 20).

MORA-URPI, J.; CLEMENT; C.R.; PLATINO, V.M. Diversidad genética em pejibaye. I. Razas y problaciones híbridas. In: CONGRESSO INTERNACIONAL SOBRE BIOLOGIA, AGRONOMIA Y INDUSTRIALIZACION DEL PIJUAYO, 4., 1993. San José. Anais, San Jose: Universidade Costa Rica, 1993. p.11-19.

MORA-URPÍ, J. Polinización en Bactris gasipaes H.B.K. (Palmae): nota adicional. Revista de Biología Tropical, San Jose, v.30, p.174-176, 1982.

MOREHOUSE, M. Food irradiation - US regulatory considerations. Rad. Phys. Chem., v. 63, p. 281-284, 2002.

MOREHOUSE, K.M. Food irradiation-US regulatory considerations. Radiat. Phys. Chem. 63 (3-6), 281-284, 2002.

MORTON, R.D. Aerobic plate count. In: DOWENS, F.P.; ITO, K. Compendium of methods for the microbiological examination of foods. 4.ed. Washington: American Public Health Association (APHA), 2001. 676p. cap.7, p.63-67

MURANO, E. A.; HAAYES, D. J.; MURANO, P. S.; OLSON, D. G.; SAPP, S. Food Irradiation - A sourcebook. USA: Ames, 1995. 
MORETTI, C.L. Processamento mínimo de hortaliças: tendências e desafios. Horticultura Brasileira, v.19, Suplemento, Palestras, jul., 2001.

MORO, J.R. Produção de palmito de pupunha. Viçosa: CPT, 1996, 28p. (CPT. Agricultura, manual, 87).

NIEMIRA, B.A. Irradiation compared with chlorination for elimination of Escherichia coli O157:H7 internalized in lettuce leaves: Influence of lettuce variety. Journal of Food Science 73:M208-M213. 2008.

NIEMIRA, B. A. Irradiation of fresh and minimally processed fruits, vegetables and juices, p. 279-300. In J. S. Novak, G. M. Sapers, and V. K. Juneja (ed.), The microbial safety of minimally processed foods. CRC Press, Boca Raton, Fla. 17, 2003

NIEMIRA, B.A., SOMMERS, C.H., FAN, X. Suspending lettuce type influences recoverability and radiation sensitivity of Escherichia coli 0157:H7. J. Food Prot. V.65, n.5, p.615-617., 2001.

NISHIKAWA, M.A.N.; MORO, J.R.; BANDEL, G. Cultura da pupunha para produção de palmito. Piracicaba: ESALQ, 1998. 31p

NGUYEN-THE, C. CARLIN, F. The microbiology of minimally processed fresh fruits and vegetables. Crit. Rev. Food Sci. Nutri., v. 34, n.4, p.371-401, 1994.

OLSON, D.G. Irradiation of food. Food Technol. v. 52, n. 1, p. 56-62, 1998.

O'MAHONY, M. Sensory evaluation of food. Estatistical methods and procedures. Davis, Califórnia. 1986. 487 p.

OUATTARA, B.; SABATO, S.F.; LACROIX, M. Use of gamma-irradiation technology in combination with edible coating to produce shelf-stable foods. Radiat. Phys. Chem., v.63, p.305-310, 2002.

PALEKAR A, SIMON D, SALOWEY J, ZHOU H, ZORN G, JOSEFSSON S. Protected EAP protocol (PEAP), IETF Draft, 2004.

PRAKASH, A. Effects of low-dose gamma irradiation on the shelf life and quality characteristics of cut Romaine lettuce packaged under modified atmosphere. Journal of Food Science 65:549-553. 2000.

PELCZAR JR, M.J; CHAN, E.C.S.; KRIEG, N.R. Microbiologia: conceitos e aplicações. 2.ed. São Paulo: McGraw-Hill, 1997. v.2. cap.30, p.372-397: Microbiologia de Alimentos. 
RAUPP, D.S.; STARON, E.A.; ALMEIDA, F.C.C.; ONUKI, N.S.; CHAIMSOHN, F.P.; BORSATO, A.V. Produção de farelo alimentar fibroso da parte caulinar do palmito Pupunha (Bactris gasipaes). Publicatio UEPG Ciências Exatas e da Terra, Ciências Agrárias e Engenharias, Ponta Grossa, v.10, n.2, p.29-36, 2004.

SÁ, C.P.; BERGO, C.L.; SANTOS, J.C.; NASCIMENTO, G.C.; GOMES, F.C.R. Coeficientes técnicos e avaliação econômica para o sistema de produção melhorado da pupunha para produção de palmito no Acre. Comunicado Técnico, 150/Embrapa Acre, Rio Branco, 2002.

STEELE, J. H. Food Irradiation: A Public Health Meansure Long Overdue. Nuclear report, Washington. p. 1-4, 1999.

SPOLAORE, A. J. G.; GERMANO, P. M. L.; GERMANO, M. I. S. Irradiação de Alimentos. In: GERMANO, P. M. L.; GERMANO, M. I. S. Higiene e Vigilância Sanitária de Alimentos. São Paulo, Livraria Varela, 2001. p. 421-442.

SOARES, A.G. Palmito de pupunha - Alternativas de processamento. Revista de Horticultura Brasileira, Brasília. v.15. p. 198-199, 1997

SOMMERS, C. H.; THAYER, D.W. Survival of surface inoculed Listeria monocytogenes on commercially available frankfurtes following gamma irradiation. Journal Food Safety., v.20, p.127-137, 2000.

TRITSCH, G. L. "Food iradiation“, Nutrition. Vol.16, n.7/8, pp. 698-701, 2000.

VAROQUAUX, P.; LECENDRE, I.; VAROQUAUX, F. et al. Change in firmness of kiwi after slicing. Sciences des Aliments, v.10, n.1, p.127-139, 1990.

VANETTI, M. C. D. Controle microbiológico e higiene no processamento mínimo. In: Encontro nacional sobre processamento mínimo de frutas e hortaliças, Viçosa. Anais Viçosa: UFV, 2000. p.44-51.

VERRUMA-BERNARDI, M.R.; Cavalcanti, A.C.D.; Kajishima, S. Aceitabilidade do palmito de pupunha. Boletim do CEPPA, 21(1): 121-130, 2003.

VILLACHICA, H. Cultivo Del pejuayo (Bactris gasipaes Kunth) para palmito en La Amazonia. Lima: TCA, 1996. 152p. 
VILLAVICENCIO ALCH, ARAÚJO MM, FANARO GB, RELA PR, MANCINIFILHO J (2007). Sensorial analysis evaluation in cereal bars preserved by ionizing radiation processing. Radiation Physics and Chemistry 76 1875-1877.

VILLAVICENCIO, A. L. C. H. Avaliação dos efeitos da radiação ionizante de 60 Co em propriedades físicas, químicas e nutricionais dos feijões Phaseolus vulgaris L. $\mathrm{e}$ Vigna unguiculata (L.) Walp. 1998. Tese (Doutorado) - FCF/USP, São Paulo.

XUETONG, F., SOKORAI, K., SOMMER, C., NIEMIRA, B AND MATTHEIS, J. Effects of calcium ascorbate and ionizing radiation on the survival of Listeria monocytogenes and product Quality of fresh-cut Gala Apples. J. Food Sci. 70 (7): 352$358,2005$.

YUYAMA, K. Melhoramento de pupunheira para produção de palmito no INPA. Manaus, Amazonas: INPA, 2005. 5p. (Relatório apresentado na Reunião Técnica do Projeto de ProBio/MMA Pupunha - Raças Primitivas e Parentes Silvestres).

YUYAMA, L.K.O.; AGUIAR, J.P.L.; YUYAMA, K.; MACEDO, S.H.M.; FÁVARO, D.I.T.; AFONSO, C.; VASCONCELLOS, M.B.A. Determinação de elementos essenciais e não essenciais em palmito de pupunheira. Horticultura Brasileira. Brasília, v.17, n.2, p.91-95, jul., 1999.

WILEY, R. C. Frutas y hortalizas mínimamente procesadas y refrigeradas. Zaragoza (Espanha): Editorial Acribia, 1997. 362p. 